\title{
The Biological Function and Therapeutic Potential of Exosomes in Cancer: Exosomes as Efficient Nanocommunicators for Cancer Therapy
}

\author{
Jeong Uk Choi ${ }^{1}$, In-Kyu Park ${ }^{2}\left(\right.$ ), Yong-Kyu Lee ${ }^{3}$ and Seung Rim Hwang ${ }^{4,5, *(\mathbb{C})}$ \\ 1 College of Pharmacy, Chonnam National University, 77 Yongbong-ro, Buk-gu, Gwangju 61186, Korea; \\ cju0667@jnu.ac.kr \\ 2 Department of Biomedical Sciences, Chonnam National University Medical School, 322 Seoyang-ro, \\ Hwasun 58128, Korea; pik96@jnu.ac.kr \\ 3 Department of Chemical and Biological Engineering, Korea National University of Transportation, \\ 50 Daehak-ro, Chungju, Chungbuk 27469, Korea; leeyk@ut.ac.kr \\ 4 College of Pharmacy, Chosun University, 309 Pilmun-daero, Dong-gu, Gwangju 61452, Korea \\ 5 Department of Biomedical Sciences, Graduate School, Chosun University, 309 Pilmun-daero, Dong-gu, \\ Gwangju 61452, Korea \\ * Correspondence: srhwang@chosun.ac.kr; Tel.: +82-62-230-6365
}

Received: 29 August 2020; Accepted: 3 October 2020; Published: 5 October 2020

\begin{abstract}
Cancer therapeutics must be delivered to their targets for improving efficacy and reducing toxicity, though they encounter physiological barriers in the tumor microenvironment. They also face limitations associated with genetic instability and dynamic changes of surface proteins in cancer cells. Nanosized exosomes generated from the endosomal compartment, however, transfer their cargo to the recipient cells and mediate the intercellular communication, which affects malignancy progression, tumor immunity, and chemoresistance. In this review, we give an overview of exosomes' biological aspects and therapeutic potential as diagnostic biomarkers and drug delivery vehicles for oncotherapy. Furthermore, we discuss whether exosomes could contribute to personalized cancer immunotherapy drug design as efficient nanocommunicators.
\end{abstract}

Keywords: exosome; cancer; nanocommunicator; diagnostic biomarker; drug delivery vehicle; personalized cancer immunotherapy

\section{Introduction}

Oncology drugs constitute the largest therapeutics section approved by the Center for Drug Evaluation and Research, a division of the United States Food and Drug Administration [1]. Once cancer metastasizes from the primary tumor to new sites at the time of detection, the survival rate of cancer patients decreases substantially, posing a threat to overall health [2]. In recent times, an early diagnosis of cancer via timely screening using liquid biopsy tools such as circulating tumor cells (CTCs) or circulating tumor DNA (ctDNA) as well as extracellular vesicles (EVs) has received attention, and the survival rate of cancer patients has increased with the development of treatment strategies [3,4].

Anticancer drug approval trends have changed since cancer chemotherapeutic agents were first developed in the 1940s. Cancer chemotherapeutics show efficacy as well as side effects as they not only interfere with the growth or division of cancer cells but also normal cells. Cancer cells even evade anticancer drugs by mediating a cellular efflux of drugs or by reducing target gene expression. They not only receive external signals but also transmit signals to form new blood vessels in cancer tissues. EVs secreted by cancer cells transfer signals for cancer progression and metastasis [5]. 
As technical limitations associated with cancer chemotherapy have been recognized, and the understanding of cancer biology has improved, the paradigm of research and development has shifted towards targeted therapy using monoclonal antibodies and small molecules that target the signaling process of cancer cells. Recently, synthetic small molecules such as a FGFR (fibroblast growth factor receptor) inhibitor (erdafitinib; Janssen Pharmaceutica, Beerse, Belgium), CSF1R (colony-stimulating factor-1 receptor)/RTK (receptor tyrosine kinase)/FLT3 (FMS-like tyrosine kinase 3) inhibitor (pexidartinib; Daiichi Sankyo, Tokyo, Japan), and exportin 1 inhibitor (selinexor; Karyopharm Therapeutics, Newton, MA, USA), and biologics such as an antibody-drug conjugate (ADC) targeting nectin-4 (enfortumab vedotin; Astellas Pharma, Tokyo, Japan), and ADC targeting CD79B (polatuzumab vedotin; Genentech/Roche, South San Francisco, CA, USA) have been approved. Interestingly, entrectinib (Genentech/Roche) simultaneously targets c-ROS oncogene 1 (ROS1), ALK (anaplastic lymphoma kinase) RTKs, and tropomyosin receptor kinase proteins encoded by neurotrophic tyrosine receptor kinase (NTRK) genes; it was approved as a biomarker-based treatment for ROS1-positive and NTRK fusion-positive cancer. In the same vein, engineered EVs that carry small interfering RNA (siRNA) or short hairpin RNA specifically targeting oncogenic KRAS mutation showed their therapeutic potential in pancreatic ductal adenocarcinoma mouse models [6].

Despite the remarkable performance of targeted anticancer drugs, limitations have been associated with the targeting of markers on the cancer cell surface, because cancer cells are genetically unstable, and surface proteins in cancer cells change dynamically during disease progression [7]. The necessity of developing new therapeutic approaches has emerged due to the genetic heterogeneity between cancer cells and drug resistance mechanisms [8]. Since 2010, cancer immunotherapy drugs including CTLA4 (cytotoxic T-lymphocyte-associated protein 4) inhibitors, PD-1 (programmed cell death protein 1) inhibitors, PD-L1 (programmed cell death ligand 1) inhibitors, and CAR (chimeric antigen receptor)-T cell therapy have received a lot of attention. As cancer cells proliferate by evading the immune system, cancer immunotherapy drugs interfere with the evasion mechanism or stimulate immune cells to attack tumor cells [9].

However, cancer therapeutics encounter barriers against transport to target sites owing to the elevated levels of solid stress, vascular network formation, interstitial fluid pressure, and density of extracellular matrix (ECM) in the tumor microenvironment [10]. Nanocarriers can enhance the permeability and retention of their cargo drugs in solid tumor tissues. Certain cancer therapeutics need to be delivered to intracellular targets such as the cytosol or nucleus to elicit their proper action [11]. Interestingly, nanosized EVs called exosomes, transfer their cargo nucleic acids and proteins to the recipient cells via the cellular uptake of vesicles; this contributes to the intercellular communication between tumor cells and bone marrow stromal cells. Recurrent mutations or specific alterations of niches within hematopoietic cells of the bone marrow regulating the production of blood and immune cells play roles in malignancy progression and chemoresistance [12]. In that exosomes orchestrate immune cells in the tumor microenvironment through cell-to-cell signaling, they have been tested for cancer immunotherapy in clinical trials. Dendritic cell (DC)-derived exosomes (DEXs) showed modest efficacy in patients with metastatic melanoma and non-small cell lung cancer (NSCLC) $[13,14]$. Autologous tumor-derived exosomes (TEXs) in combination with the GM-CSF (granulocyte-macrophage colony-stimulating factor) could induce antitumor T lymphocyte response in colorectal cancer [15]. TEXs can also provide diagnostic biomarkers, because they circulate in biological fluids and the exosomal components enclosed in lipid membrane vesicles reflect the characteristics of the cells of origin in the tumor tissue.

In this review, we aimed to provide a comprehensive overview of the biological aspects and potential therapeutic applications of exosomes in cancer. Here, we also discuss whether exosomes could contribute to personalized cancer immunotherapy drug design as efficient nanocommunicators. 


\section{Biologic Aspects of Exosomes and Cancer}

\subsection{Exosome Biogenesis}

Cells release EVs enclosed in lipid membranes into the extracellular environment. Exosomes, microvesicles (MVs)/microparticles, and apoptotic bodies form a subgroup of EVs. They have been defined by their biogenesis, size, or constituent molecules. The process of exosome biogenesis starts with endocytic membrane transport through which the cell surface proteins can be recycled [16]. The perimeter membrane of endocytic vesicles buds inward during endosome maturation from the early endosome to the late endosome [17]. Further invagination of the endosomal membrane into the endosomal compartment forms intraluminal vesicles (ILVs) in the multivesicular body (MVB). Subsequently, the MVB is either fused with the lysosome for degradation or release its contents in the form of exosomes by merging with the plasma membrane [18]. This process of exosome formation is different from that of MV/microparticle formation that takes place via outward budding directly from the plasma membrane (Figure 1) [18].

The most well-known mechanism for packaging receptors internalized from the cell surface and other exosomal cargo proteins in the late endosome membrane depend on the endosomal sorting complex required for transport (ESCRT) machinery [19]. Cytosolic protein complexes composed of ESCRT-0, ESCRT-I, ESCRT-II, and ESCRT-III, together with accessory proteins, participate in binding ubiquitinated cargo and sculpting MVB vesicles [20]. The addition of a regulatory ubiquitin protein to the substrate is a reversible post-translational modification catalyzed by a ubiquitin-activating enzyme, ubiquitin-conjugating enzyme, and ubiquitin ligase [21]. Even though it is debatable whether the contents of MVBs are released into the extracellular medium or enter the lysosome under certain circumstances, the tagging of misfolded or damaged proteins with ubiquitin plays a role in maintaining intracellular protein levels for cell cycle regulation and is also associated with the oncogenic processes [22]. For example, mutations in genes encoding components for ubiquitin ligase activity lead to the development of renal cell carcinoma and breast cancer $[23,24]$.

Alternatively, ESCRT-independent pathways are supported by MVB formation even in the depletion of key subunits of ESCRTs [25]. Sphingolipids and cholesterol that are enriched in detergent-resistant membrane domains may be involved in ubiquitin-independent protein sorting [26]. The sphingolipid ceramide also triggers the formation of ILVs in the late endosome that are destined for secretion as exosomes [27]. Observation of human lymphoblastoid cells via immunoelectron microscopy demonstrated low cholesterol labeling in the lysosome but high cholesterol labeling in the MVB and exosomes [28]. Despite the possibility of ubiquitin-independent exosomal cargo sorting, certain ESCRT components are involved in exosome formation. Apoptosis-linked gene 2-interacting protein X (ALIX), an ESCRT accessory protein, contributes to the sorting of transferrin receptor into the late endosome membrane and interacts with syntenin-linking syndecan-mediated signaling $[29,30]$. Hepatocyte growth factor-regulated tyrosine kinase substrate (HRS), an ESCRT-0 protein, is related to exosomal secretion and antigen-presenting activity in DCs [31].

The pathways of packaging RNAs into exosomes are still unclear. Specific linear sequence motifs that are shared by exosomal RNAs may function as cis-acting elements that target RNAs to exosomes [32]. GW-bodies containing protein components of RNA-induced silencing complex congregate with the endosome and MVB, where microRNA (miRNAs) are enriched. The exosome-like vesicles secreted by MVBs are rich in GW182, which modulates miRNA loading or gene silencing [33].

\subsection{Exosome-Cell Interaction and Biodistribution of Exosomes}

After being secreted by the original cell into the extracellular space, exosomes circulate in body fluids or are distributed into the tissue ECM $[34,35]$. Owing to their nanosize, they even penetrate the nasal mucosa and bypass the blood-brain barrier [36]. Labeling and tracking exosomes using fluorescence or bioluminescence helps us understand exosome-cell interaction and the biodistribution of exosomes [37]. 
Exosomes with lipid bilayer structures can be taken up into the recipient cell via membrane fusion, clathrin-mediated endocytosis, caveolin-dependent endocytosis, macropinocytosis, or phagocytosis, leading to the delivery of exosomal contents to the cytosolic space of the recipient cell (Figure 2) [38-41]. Exosomal cargo is then released by the acidification of the endo/lysosome compartment in the recipient cell [42]. Receptor-ligand interactions between cell surface receptors and exosomal ligands may also occur based on specific cell types, and mediate antigen presentation, cell signaling, the release of soluble factor, disease progression, and immune surveillance [43].

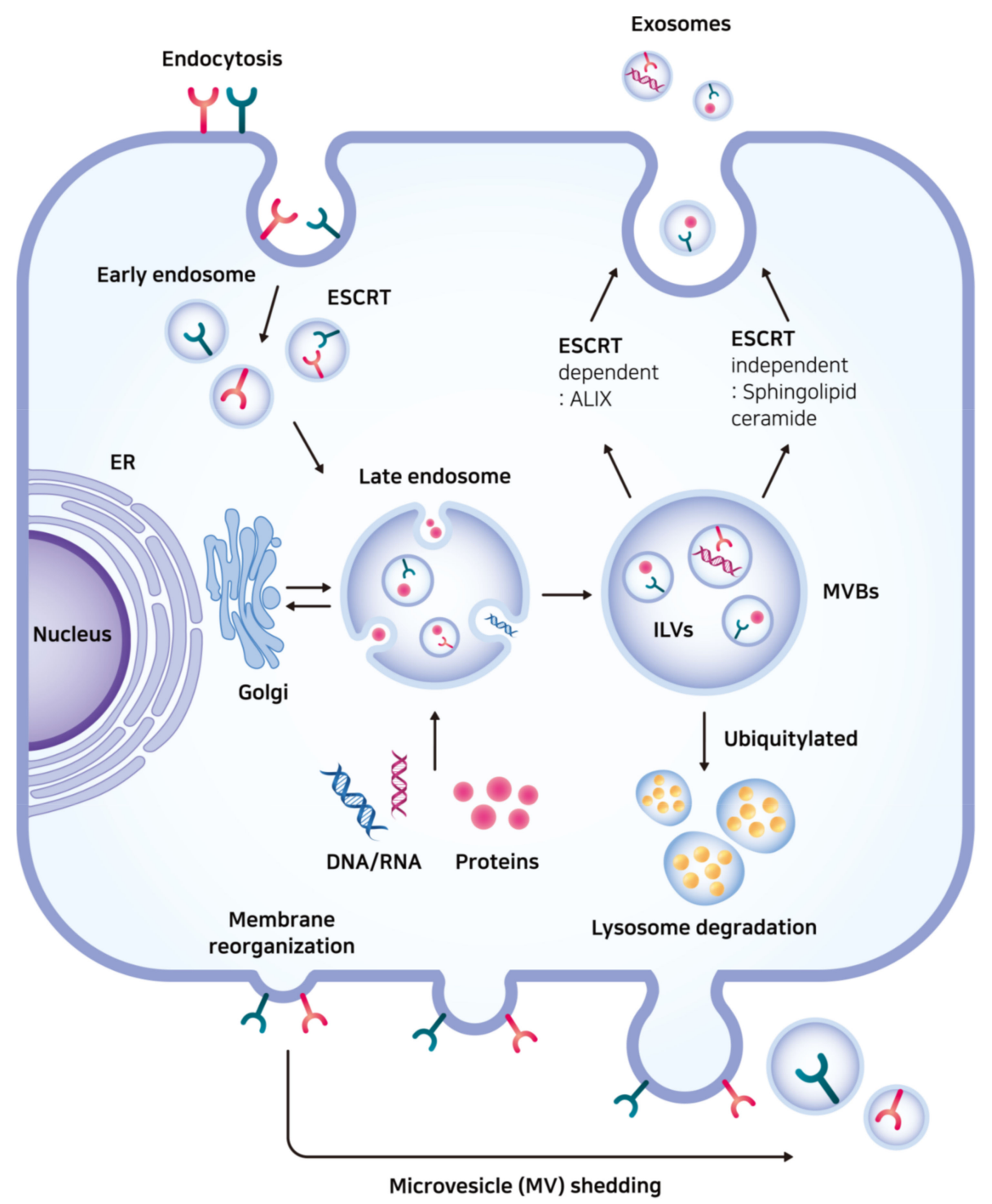

Figure 1. The process of exosome biogenesis. The perimeter membrane of endocytic vesicles buds inward during endosome maturation from the early endosome to the late endosome. Further invagination of the endosomal membrane forms intraluminal vesicles (ILVs) in the multivesicular body (MVB). Subsequently, the MVB is fused with the lysosome or release its contents in the form of exosomes (top right). This process of exosome biogenesis is different from that of microvesicle (MV) shedding (bottom). Receptors internalized from the cell surface and other exosomal cargo proteins are packed in the late endosome either by endosomal sorting complex required for transport (ESCRT)-dependent or ESCRT-independent pathway. ER: endoplasmic reticulum; ILV: intraluminal vesicle; MVB: multivesicular body; MV: microvesicle; ESCRT: endosomal sorting complex required for transport; ALIX: apoptosis-linked gene 2-interacting protein $\mathrm{X}$. 


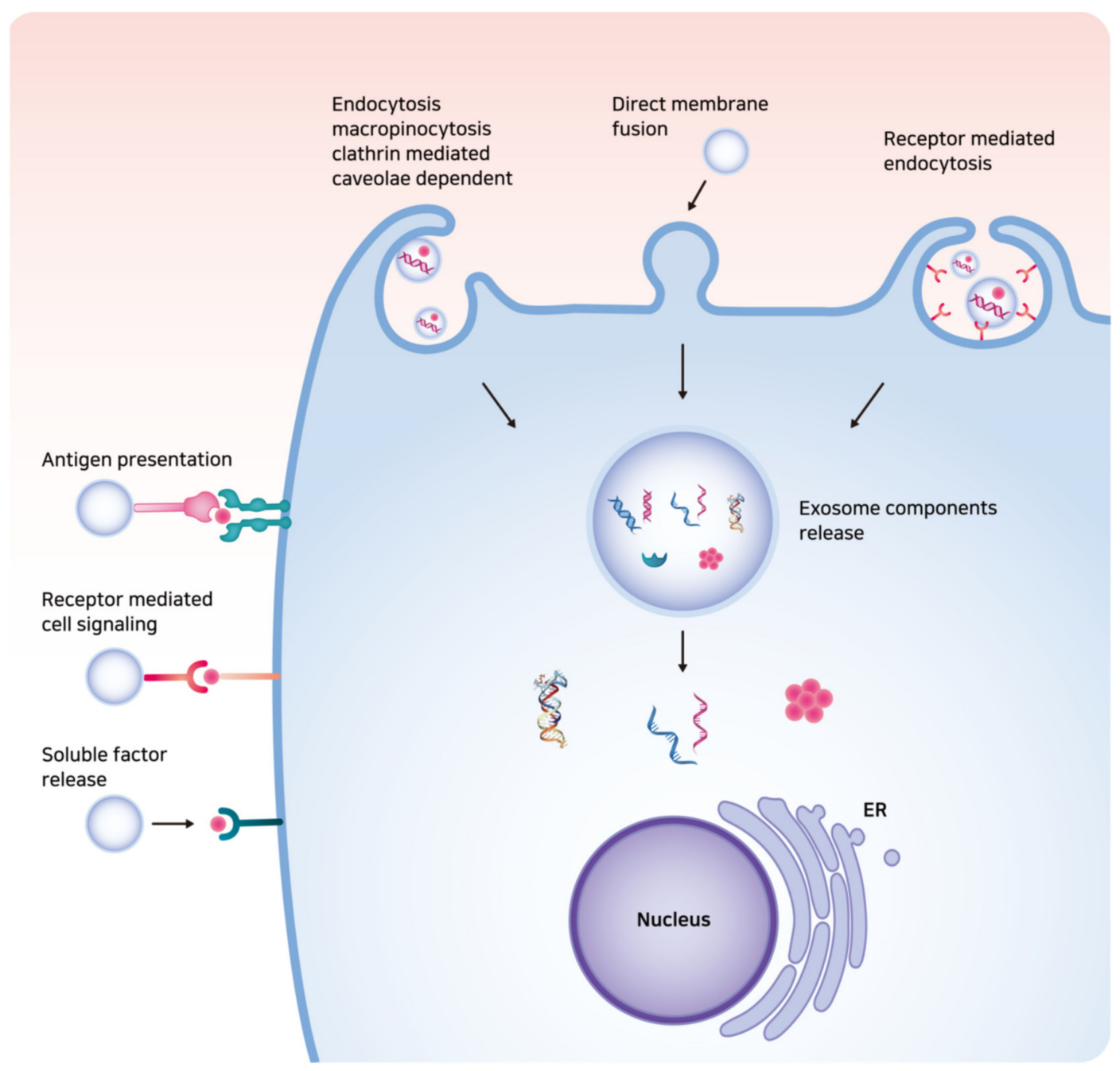

Figure 2. The illustration of exosome-cell interaction. Exosomes can be taken up into the recipient cell via direct membrane fusion or endocytosis, leading to the delivery of exosomal contents such as DNAs, messenger RNAs, long non-coding RNAs, enzymes, and signaling peptides or proteins to the cytosolic space of the recipient cell. Receptor-ligand interactions between cell surface receptors and exosomal ligands may also occur.

The diverse functions of exosomes are governed by the delivery of exosomal components, including lipids, nucleic acids, and proteins such as tetraspanins, adhesion molecules, antigen-presenting molecules, transmembrane receptors, MVB formation proteins, membrane trafficking proteins, cytoskeletal proteins, enzymes, signaling proteins, and heat shock proteins (Figure 3) [44]. Finally, clearance of exosomes from the body might take place via the liver, spleen, and kidneys with the mononuclear phagocytic system [45].

\subsection{The Biological Functions of Exosomes in Cancer}

Exosomes function as unique intercellular communicators and debris managers for cellular homeostasis [46]. Delivery of exosomal cargo mediates cell motility, immune responses, and reprogramming of the tumor microenvironment. Whether exosomes promote cancer progression and escape from immunosurveillance depends on the type of the cells of origin and malignancy at the time of exosome release [47,48]. TEXs have autocrine and paracrine roles in cancer progression [49]. At the site of the primary lesion, they carry fibronectin and proteinases, including membrane type 1-matrix metalloproteinase (MMP) and MMP2, and facilitate adhesion and invasiveness of cancer cells [50]. Delivery of miRNAs via TEXs 
transforms fibroblasts into cancer-associated fibroblasts (CAFs) [51-53]. Meanwhile, fibroblast-derived exosomes have been reported to stimulate directional movements of breast cancer cells, which is dependent on Wnt-planar cell polarity signaling [54]. Exosomes secreted from CAFs are rich in disintegrin and metalloproteinase domain-containing protein 10 , which can enhance cancer cell motility via Notch receptor activation and the GTPase RhoA signalling [55]. Adipocyte-derived exosomes have been shown to increase migration and invasion of melanoma cells via fatty acid oxidation [56].

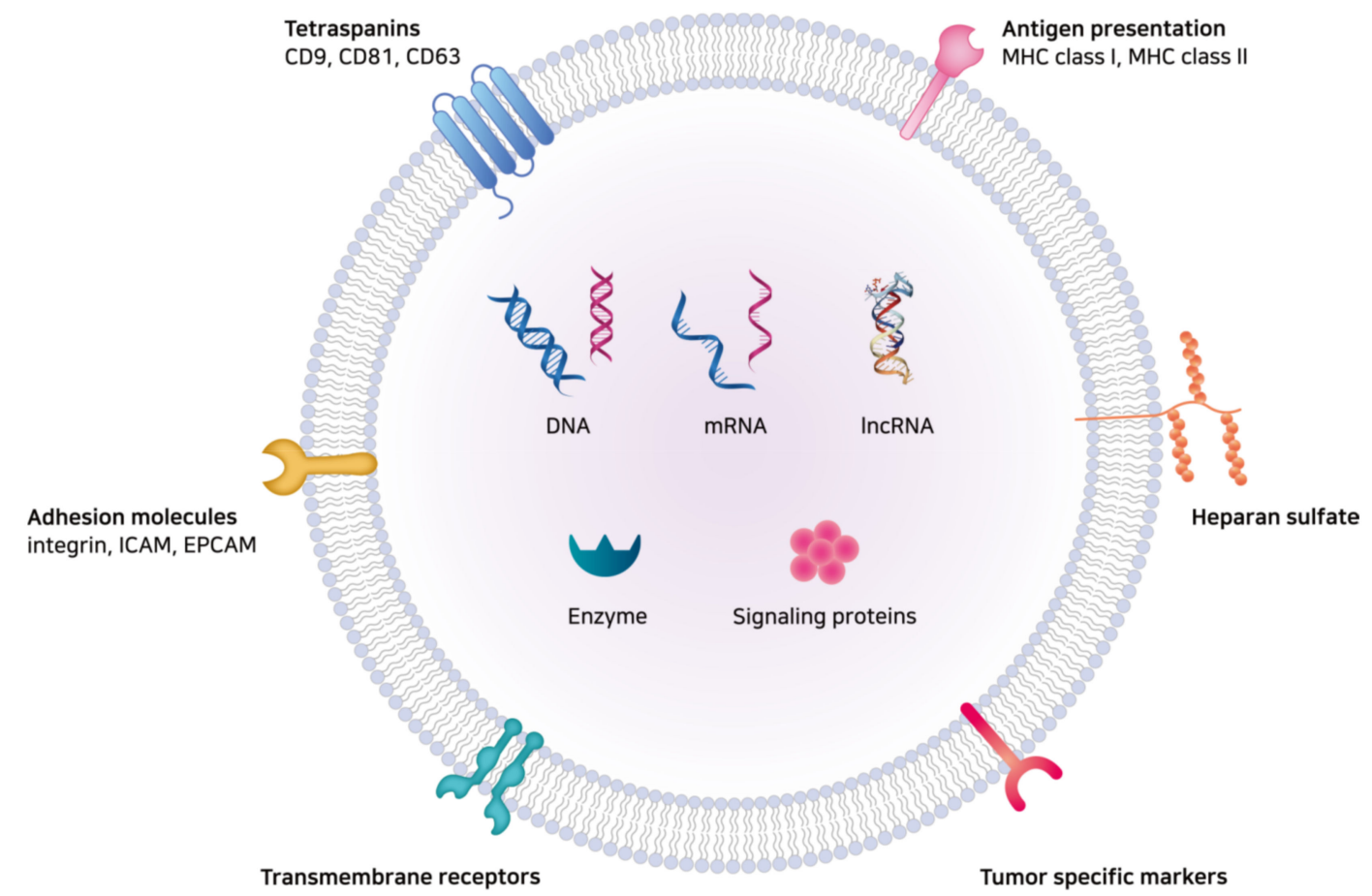

Figure 3. The illustration of exosomal components. The diverse functions of exosomes are governed by the delivery of exosomal cargo proteins and nucleic acids to the recipient cells. Exosomal components include lipids, nucleic acids, tetraspanins, adhesion molecules, antigen-presenting molecules, transmembrane receptors, MVB formation proteins, membrane trafficking proteins, enzymes, signaling proteins, etc. mRNA: messenger RNAs; lncRNA: long non-coding RNA; ICAM: intercellular adhesion molecule; EpCAM: epithelial cell adhesion molecule; MHC: major histocompatibility complex.

Exosomes also regulate angiogenesis and vascular permeability [57]. A mucin-type podoplanin glycoprotein, which is upregulated in certain types of cancer and incorporated into exosomes, reprograms exosomal proteins and promotes lymphangiogenesis [58]. Uptake of leukemia-derived exosomes containing miR-92a by endothelial cells enhanced endothelial tube formation [59]. Exosomes released by metastatic tumor cells led to endothelial hyperpermeability contrary to the exosomes released by non-metastatic tumor cells [60]. Under hypoxia, miR-23a upregulation in TEXs leads to the accumulation of hypoxia-inducible factor- $1 \alpha$, enhancing angiogenesis, and inhibits tight junction protein ZO-1, increasing vascular permeability [61].

After the intravasation of tumor cells, TEXs traveling through the bloodstream develop "pre-metastatic niches" by modifying microenvironments in distant target organs and affecting organ-specific stromal cells [62]. Exosomes from highly metastatic melanomas reprogrammed bone marrow progenitor cells, resulting in exosome-mediated tyrosine-protein kinase Met signaling [63]. Uptake of exosomes derived from pancreatic ductal adenocarcinomas by Kupffer cells induced transforming growth factor- $\beta$ secretion and fibronectin production, which initiated liver pre-metastatic niche formation [64]. Specific integrin expression patterns on TEXs were shown to correlate with the localization of TEXs and organotropic metastasis [65]. Targeting the exosomal integrin $\alpha_{6} \beta_{4}$ was associated with lung metastasis, whereas targeting the exosomal integrin $\alpha_{\mathrm{v}} \beta_{5}$ was associated with liver 
metastasis. TEXs can also enter sentinel lymph nodes and influence lymph node distribution of cancer cells, which is driven by synchronized molecular signals that affect tumor metastasis [66]. Meanwhile, reports indicate that exosomes from non-metastatic cells inhibit metastasis. Exosomes isolated from non-metastatic patient sera suppressed experimental lung metastasis by increasing the number of patrolling monocytes in the lungs and inducing macrophage differentiation, leading to immune surveillance in the pre-metastatic niche [67].

As TEXs contain immunosuppressive ligands as well as immunostimulatory tumor-associated antigens (TAAs), they can play roles in mediating tumor immunity [68]. Binding immune-inhibitory ligands of TEXs to T cell receptors and IL-2 receptors leads to tolerogenic signals [69]. TEXs also induce apoptosis of $\mathrm{CD}^{+} \mathrm{T}$ lymphocytes and differentiation of myeloid precursor cells and regulatory $\mathrm{T}$ cells. They can also inhibit the cytotoxic functions of natural killer (NK) cells via downregulation of NK group 2D, an NK-activating receptor that recognizes ligands on the surface of malignant cells as well as TEXs [70]. Meanwhile, DEXs pulsed with tumor peptides activate cytotoxic T lymphocytes [71]. Mast cell-derived exosomes associated with antigens induce maturation of DCs. Antigen presentation by DCs activates B and T cells [72].

Exosomes have also been reported to mediate cancer chemoresistance by cargo transfer [73]. Exosomes derived from drug-resistant breast cancer cells modulated the cell cycle and drug-induced apoptosis, which might be dependent on selective miRNA patterns [73]. Restoration of miR-151a via exosomes derived from temozolomide (TMZ)-resistant glioblastoma multiforme enhances chemosensitivity to TMZ, whereas miR-151a loss drives TMZ resistance [74]. In cisplatin-resistant tumor cells, acidic $\mathrm{pH}$ in the extracellular microenvironment reduces cisplatin uptake into tumor cells and increases cisplatin levels eliminated via TEXs [75]. Exosomes isolated from fibroblast-derived conditioned medium prime cancer stem cells and promote chemoresistance in colorectal cancer [76]. Transfer of exosomal RNA from stromal to breast cancer cells activates signal transducer and activator of transcription 1 and NOTCH3 signaling, which regulate the expansion of chemoresistant cancer cells [77].

\section{Potential Therapeutic Applications of Exosomes in Cancer}

\subsection{Exosomes as Diagnostic Biomarkers for Cancer}

\subsubsection{Identification Techniques of Exosomes in Liquid Biopsy}

As exosomes have the potential to be used as prognostic biomarkers, isolation and identification of exosomes and their contents are also critical issues. For exosome isolation/purification, various methods have been evaluated. The most common method is differential centrifugation at $300 \times g$ for $10 \mathrm{~min}$, $2000 \times g$ for $10 \mathrm{~min}$, and $10,000 \times g$ for $30 \mathrm{~min}$, followed by ultracentrifugation at $100,000 \times g$ for $2 \mathrm{~h}$. For higher purity of exosomes, gradient centrifugation using sucrose can also be used [78]. An immuno-isolation method using antibody-coated magnetic beads can also be used to obtain higher purity and recovery rates. Rapid surface protein characterization using flow cytometry provides additional benefits with this method [79]. However, only specific types of exosomes can be isolated using this method, which can be considered as one of the limitations of this method. Currently, exosome extraction kits such as the ExoSpin ${ }^{\mathrm{TM}}$ Exosome purification Kit (Cell Guidance Systems LLC; St. Louis, MO, USA) and Total Exosome Isolation Kit ${ }^{\mathrm{TM}}$ (Life Technologies; Waltham, MA, USA) are also available. Typically, these kits use polymers such as polyethylene glycol with centrifugation to induce exosome sedimentation [80]. Microfluidic technology enables rapid and precise isolation/purification of exosomes with a very small volume of samples using a micro-electromechanical system [81]. Turbidimetry-enabled particle purification liquid chromatography based on the size exclusion principle also has been proven superior in purification of EVs in biofluids [82]. Using biosensors is another technique to determine exosomes with higher sensitivity and automated analysis [83]. For identification of exosome contents, general methods such as polymerase chain reaction (PCR), next-generation sequencing (NGS), and proteomics can be used. 


\subsubsection{Applications of Exosomes as Diagnostic Biomarkers for Cancer}

Liquid biopsy tools such as CTCs, ctDNA, and exosomes have advantages in non-invasive diagnosis and prognosis over traditional tissue biopsy strategies. Prognostic potential of CTCs has been already tested for monitoring epithelium-originating tumors in clinical trials [84]. However, CTCs shed from the primary tumor are found as only a few CTCs per $\mathrm{mL}$ of blood among millions of erythrocytes or leukocytes, and CTC enrichment techniques are needed for their detection [85]. Fragmented DNA shed from tumor cells may reflect the genetic signature of tumors [86]. Analysis of ctDNA in blood is challenging because there is a small fraction of ctDNA among cell-free DNAs from leukocytes in the blood sample [87]. In addition, the heterogeneity of tumor cells makes determining tumor-specific mutation in the ctDNA sample difficult.

Compared to the limited amounts of CTCs or ctDNA in the bloodstream, exosomes can be detected not only in blood but also in urine, cerebrospinal fluid, or lymphatic exudate $[88,89]$. Exosomes can be actively involved in cellular communication by delivering various signaling molecules. They serve as effective carriers, as the lipid bilayer can protect the contents and directly deliver them to the target cells. Exosome contents include nucleic acids, enzymes, and various signaling proteins. The contents can vary depending on the cells of origin. Therefore, the identification of exosomal contents can provide important clues regarding the cells of origin, which makes them ideal biomarkers for the diagnosis of diseases such as cancer, infection, metabolic, and neurodegenerative disorders $[90,91]$.

As exosomes and their contents released from cancer cells display unique properties, many attempts have been made to use TEXs as cancer diagnostic biomarkers (Table 1) [92]. TEXs play important roles in facilitating tumor growth and are involved in every step of cancer development, including angiogenesis, proliferation, metastasis, and fostering the tumor microenvironment by delivering relevant genes, growth factors, and cell signaling molecules [93-95]. For example, exosomes isolated from urine samples can be used to diagnose prostate cancer, bladder cancer, and glioblastoma. Typically, exosomal proteins related to epidermal growth factor receptor (EGFR) pathways (resistin, $\alpha$-subunit of Gs protein, retinoic acid-induced protein 3, EGFR variant III, etc.) are present at diagnostic levels and hence, can be used as reliable biomarkers [96-98]. Prostate-specific antigen, survivin, and prostate cancer antigen 3 in exosomal contents can be also used for detecting prostate cancer $[97,99,100]$. Nucleic acids present in cancer exosomes, including miRNA, messenger RNA (mRNA), and long non-coding RNA (lncRNA), can also be used as diagnostic markers. For example, unique nucleic acids from exosomes have been identified in patients with glioblastoma [98]. Specific IncRNA, LINC00152, was also identified in gastric cancer-derived exosomes, which makes it a useful diagnostic biomarker [101]. miRNAs such as miR-21,-141,-200a, etc. can be detected in ovarian cancer patients, and miR-17-3p,-21, etc. were identified in lung cancer patients [102,103]. The genetic mutation in cancer patients is detectable by using exosome samples instead of CTCs or ctDNA. Exosomal RNA/DNA demonstrated the diagnostic value for KRAS mutation in pancreatic cancer and EGFR mutation in NSCLC [104-106]. BRAF mutation in EVs from lymphatic exudate of melanoma patients was reported to be useful for the prognosis [107]. Therefore, identification of unique exosomal contents corresponding to various types of cancers can help develop reliable diagnostic biomarkers (Figure 4).

\subsection{Exosomes as Drug Delivery Vehicles for Oncotherapy}

Exosomes are attractive nanovehicles for targeting cancer (Figure 4). As exosomes originate from endogenous cells, they possess low immunogenicity and thus induce low toxicity and side effects [108]. Exosomes are stable under physiological conditions. Owing to the presence of a lipid bilayer, they can protect the contents from the immune system and various enzymes. Furthermore, they demonstrate a homing capability by cell/tissue tropism with a longer circulation period, and can also cross the blood-brain barrier [109]. Unlike liposomes or other synthetic drug delivery nanoparticles, exosomes have characteristic membrane proteins and lipids that promote efficient targeting of exosomes to the recipient cell [110]. Exosomes can also enhance the delivery of contents as they can be directly fused or internalized into target cells. CD47, an integrin-associated protein upregulated in mesenchymal 
stem cells (MSCs), interacts with signal-regulatory protein, which helps inhibition of phagocytosis [111]. Thus, exosomes derived from fibroblast-like MSCs show the enhanced retention in the circulation in mice [6]. As the average size of exosomes ranges from 30 to $200 \mathrm{~nm}$, passive targeting of exosomes to tumor tissue with enhanced permeability and retention effect can also be expected. With these benefits, a number of clinical and preclinical trials have been conducted to utilize exosomes as delivery vehicles.

Table 1. Applications of exosomes as diagnostic biomarkers for cancer.

\begin{tabular}{clll}
\hline Exosome Contents & \multicolumn{1}{c}{ Associated Molecule } & \multicolumn{1}{c}{ Target Disease } & Reference \\
\hline \multirow{2}{*}{ Proteins } & $\begin{array}{l}\text { Resistin, } \\
\alpha \text {-subunit of Gs protein, } \\
\text { retinoic acid-induced protein 3 } \\
\text { Epidermal growth factor receptor } \\
\text { (EGFR) variant III }\end{array}$ & Prostate, bladder cancer & {$[96,97]$} \\
& $\begin{array}{c}\text { Prostate-specific antigen, survivin, } \\
\text { prostate cancer antigen 3 }\end{array}$ & Prostate cancer & {$[98]$} \\
lncRNA, LINC00152 & Gastric cancer & {$[97,99,100]$} \\
miR-21, miR-141, miR-200a & Ovarian cancer & {$[101]$} \\
DNAs & miR-17-3p, miR-21 & Non-small cell lung cancer & {$[102]$} \\
& Mutant KRAS & (NSCLC) & {$[103]$} \\
& EGFR T790M mutation & Pancreatic cancer & {$[104]$} \\
& Mutant KRAS, TP53 & Pancreatic cancer & {$[105]$} \\
& BRAFV60E mutation & Melanoma & {$[106]$} \\
\hline
\end{tabular}

EGFR: epidermal growth factor receptor; NSCLC: non-small cell lung cancer.

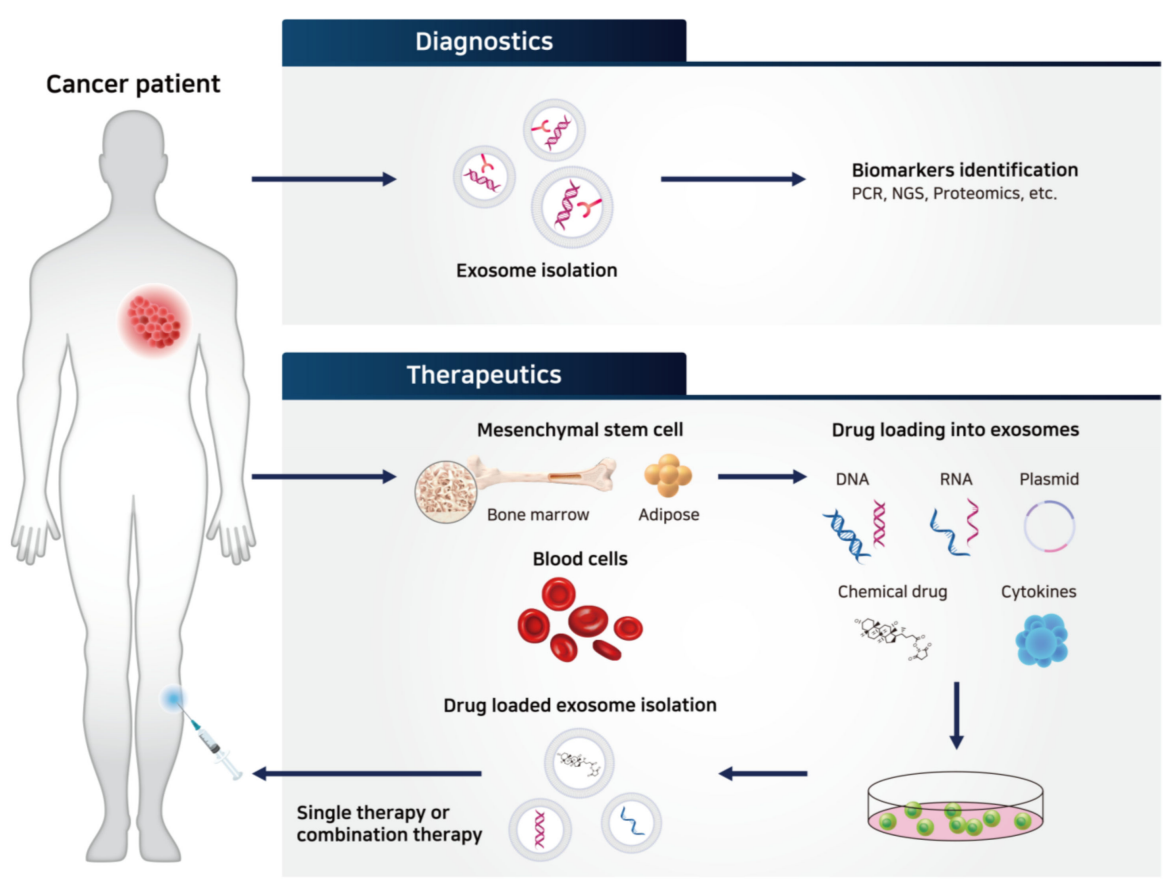

Figure 4. Potential therapeutic applications of exosomes in cancer. As exosomal components reflect the characteristics of the cells of origin, many attempts have been made to use tumor-derived exosomes (TEXs) as cancer diagnostic biomarkers. For identification of exosome contents, general methods such as polymerase chain reaction (PCR), next-generation sequencing (NGS), and proteomics can be used. Exosomes also have therapeutic potential as nanovehicles for drug delivery and personalized cancer immunotherapy. TEX: tumor-derived exosome; PCR: polymerase chain reaction; NGS: next-generation sequencing. 


\subsubsection{Methods for Loading Drugs into Exosomes}

A number of studies have demonstrated that drug-loaded exosomes show better outcomes in inhibiting cancers, but the methods for loading drugs into exosomes also need to be explored further because they are closely related to the stability and loading efficiency of the drugs. To date, there are three types of drug loading methods for exosomes: exogenous loading, endogenous loading, and liposome fusion loading [108]. Exogenous loading refers to the method that directly entraps the drugs inside an isolated exosome with simple incubation, sonication, electroporation, repeated freeze/thaw, and extrusion [112]. Simple incubation can be easily used, but the average loading efficiency of paclitaxel into EVs was below $10 \%$. Sonication can elevate the average loading efficiency up to $28.29 \%$, but affecting the loading amount of hydrophobic drugs by altering the membrane of the exosome is an issue [113]. Typically, the exogenous loading method is advantageous in maintaining the aqueous stability of drug-loaded exosomes over one month at $4{ }^{\circ} \mathrm{C}$ and $37^{\circ} \mathrm{C}$, but it is limited by relatively low loading efficiency. Endogenous loading refers to a method that entraps desired molecules in exosomes by modifying the cells of origin before the isolation of exosomes. For instance, treating host cells with chemical drugs, such as paclitaxel, can induce the release of exosomes loaded with paclitaxel [114]. For protein or gene delivery, host cells can be transfected with desired genes, which facilitates the release of exosomes with desired proteins or genes [115]. Although the endogenous loading method demonstrates a relatively high loading efficiency, it is difficult to quantify the amount of content inside the exosome and maintain high purity. Exosomes used in membrane protein engineering approaches protect their cargo proteins, but can be degraded by proteinase [116]. The liposome fusion method uses the hybridization of drug-loaded liposomes and exosomes by the freeze/melting process. This fusion method exhibits higher loading efficiency, especially for loading large plasmids, including CRISPR-Cas9 expressing vectors [117]. However, it is unclear whether this hybridized liposome-exosome can maintain the unique properties of exosomes [118]. Hence, further comprehensive evaluation of parameters such as targetability, half-life, and side effects for hybridized liposome-exosome is required.

\subsubsection{Delivering Chemical Drugs via Exosomes for Oncotherapy}

As many of chemical drugs can act after being internalized into cancer cells, they need to diffuse through the cell membrane to exert cytotoxicity, which is one of the factors reducing the efficacy of drugs [108]. In this aspect, exosomes can be potential candidates for delivering chemical drugs directly into the target cells. Many trials have been conducted to deliver chemical drugs such as paclitaxel, doxorubicin, cisplatin, and curcumin by packaging into exosomes for the treatment of various cancers (Table 2). For instance, paclitaxel-loaded exosomes isolated from MSCs, macrophages, and prostate cancer cells enhanced antitumor efficacy against pancreatic, breast, prostate, and Lewis lung carcinomas both in in vitro and in vivo studies $[113,114,119,120]$. Similarly, doxorubicin-loaded exosomes were also examined either by using the mechanical extrusion method to obtain higher drug loading efficiency [121] or surface engineering of exosomes to enhance targetability [122] for the treatment of colon and breast cancers, respectively. Treatment with cisplatin-loaded exosomes could prolong the survival rate of mice with ovarian cancer compared to the free cisplatin-treated group [123]. Pancreatic cancer-derived exosomes containing curcumin also effectively induced apoptosis in pancreatic cancer cells [124]. These studies show that by using exosomes as delivery vehicles, chemical drugs can be delivered more efficiently to target cells, which results in better outcomes. 
Table 2. Exosomes as drug delivery vehicles for oncotherapy in preclinical studies.

\begin{tabular}{|c|c|c|c|}
\hline Therapeutic Molecules & Exosome Origin & Targeted Disease & Reference \\
\hline \multicolumn{4}{|l|}{ Chemical drugs } \\
\hline \multirow[t]{3}{*}{ Paclitaxel } & Macrophage & Lewis lung carcinoma & [113] \\
\hline & MSC & Pancreatic, breast cancer & {$[114,119]$} \\
\hline & Prostate cancer cell & Prostate cancer & [120] \\
\hline \multirow{2}{*}{ Droxorubicin } & U937 RAW264.7 & Colon cancer & [121] \\
\hline & DCs expressing iRGD & Breast cancer & [122] \\
\hline Cisplatin & Hepatocarcinoma cell & Hepatocarcinoma & [123] \\
\hline Curcumin & Pancreatic cancer cell & Pancreatic cancer & [124] \\
\hline \multicolumn{4}{|l|}{ Proteins } \\
\hline TRIM3 & Gastric cancer cell & Gastric cancer & [125] \\
\hline CD-UPRT fusion protein & HEK293T & Schwannoma & [126] \\
\hline TRAIL & K562 & Lymphoma & [127] \\
\hline $\begin{array}{l}\text { MHC class I/peptide } \\
\text { complex }\end{array}$ & DC & Breast cancer & [128] \\
\hline HSP70 & Myeloma cell & Myeloma & [129] \\
\hline EGFR nanobodies & Myeloid leukemia cell & Epidermal carcinoma & [130] \\
\hline SIRP $\alpha$ & Embryonic kidney cell & Colon cancer & [131] \\
\hline \multicolumn{4}{|c|}{ 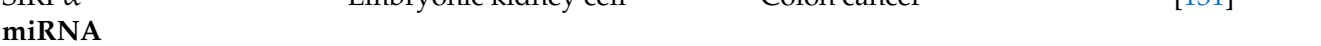 } \\
\hline miR-145-5p & MSC & Pancreatic cancer & [115] \\
\hline Let-7a & HEK293T expressing GE11 & Breast cancer with EGFR & [132] \\
\hline miR-146b & MSC & Glioma & [133] \\
\hline miR-122 & MSC & Hepatocellular carcinoma & [134] \\
\hline miR-335-5p & Stellate cell & Hepatocellular carcinoma & [135] \\
\hline miR-379 & MSC & Breast cancer & [136] \\
\hline $\begin{array}{l}\text { miR-25-3p inhibitor } \\
\text { siRNA }\end{array}$ & \multicolumn{2}{|c|}{ siRNA } & [137] \\
\hline PLK-1 siRNA & HEK293T + MSC & Bladder cancer & [138] \\
\hline GRP78 siRNA & MSC & Hepatocellular carcinoma & [139] \\
\hline \multicolumn{4}{|l|}{ mRNA } \\
\hline Cas9 mRNA & Red blood cell & Breast cancer & [141] \\
\hline PTEN mRNA & $\begin{array}{l}\text { Mouse embryonic fibroblast } \\
\text { serum }\end{array}$ & Glioma & [142] \\
\hline ECRG4 mRNA & Neuroblastoma cell & Tongue carcinoma & [143] \\
\hline
\end{tabular}

MSC: mesenchymal stem cell; DC: dendritic cell; TRIM: tripartite motif-containing protein; CD: cytosine deaminase; UPRT: uracil phosphoribosyltransferase; TRAIL: TNF-related apoptosis-inducing ligand; MHC: major histocompatibility complex; HSP: heat shock protein; EGFR: epidermal growth factor receptor; SIRP: signal-regulatory protein; PLK: polo-like kinase; Cas: CRISPR associated protein; PTEN: phosphatase and tensin homolog; ECRG: esophageal cancer related gene.

\subsubsection{Delivering Therapeutic Proteins via Exosomes for Oncotherapy}

As the efficacy of many proteins is limited due to several barriers such as short half-life, low delivery rate, and induction of resistance, the use of appropriate delivery vehicles is one of the best ways to achieve successful protein drug therapies. As exosomes can protect the contents from various enzymes and the immune system, they can act as effective delivery vehicles for proteins. Proteins can be loaded either inside or on the surface of the exosome, based on the mechanism of action of the drugs. However, as therapeutic proteins are macromolecules, it is difficult to directly incorporate them into exosomes. Therefore, genetic modification of the cells of origin leading to the expression of therapeutic proteins in exosomes is usually preferred to prepare protein-loaded exosomes. Several preclinical studies regarding protein-loaded exosomes are summarized in Table 2. For example, the delivery of tripartite motif-containing protein 3 (TRIM3) using gastric cancer-derived exosomes successfully suppressed the proliferation, migration, and metastasis of gastric cancer [125]. Similarly, apoptosis-inducing proteins such as suicide-inducing fusion protein or TNF-related apoptosis-inducing ligand (TRAIL) were loaded into exosomes, and this method could elicit substantially reduced tumor growth in in vivo tumor models $[126,127]$. Some signaling-related proteins can be expressed on the surface of exosomes to improve tumor immunity, such as the major histocompatibility (MHC) class I/peptide complex [128]. In other studies, immunogenic proteins such as HSP70 were loaded onto exosomes, which resulted in 
enhanced antitumor T cell activity [129]. Some studies have shown that EGFR nanobodies anchored on exosomes via glycosylphosphatidylinositol (GPI) could bind to EGFR-expressing tumor cells with higher affinity [130].

\subsubsection{Delivering RNA Drugs via Exosomes for Oncotherapy}

Similar to therapeutic proteins, delivery vehicles are an essential component of successful gene therapy. Exosomes can protect genes from various enzymes, such as DNases and RNases, and can also directly deliver genes inside the cells, which enhances their therapeutic efficacy. Different types of RNAs such as mRNA, miRNA, and siRNA are promising candidates for the treatment of cancers. Studies on exosome RNA delivery are summarized in Table 2. miRNAs are non-coding RNAs involved in the regulation of gene expression. Pathophysiological conditions such as cancer are usually characterized by abnormal expression of certain types of miRNAs, which suggests that targeting miRNAs could be an effective way to treat cancer [144]. Treatment with exosomes overexpressing miR-122 showed substantially elevated chemosensitivity in hepatocellular carcinoma [134]. As the downregulation of miR-335-5p in both hepatocellular carcinoma and stellate cells acts as a pro-tumorigenic factor, delivery of miR-335-5p-overexpressing exosome exhibited substantial tumor shrinkage in an in vivo tumor model [135]. Similarly, treatment with miR-379-overexpressing exosomes significantly suppressed tumor growth in a T47D breast tumor model [136]. In addition, miR-145-5p overexpression inhibited the proliferation of pancreatic ductal adenocarcinoma and induced tumor cell apoptosis in an in vivo model [115]. In addition, specific miRNA inhibitors could act as potential drug candidates. For example, miR-25-3p is known to play an important role in facilitating colorectal cancer metastasis and promoting angiogenesis by targeting KLF (Kruppel-like factor)-2 and KLF-4, which implies that miR-25-3p can be a promising target for treating colorectal cancer. One study showed that treatment with exosomes loaded with miR-25-3p inhibitor considerably attenuated the tumor metastasis of colorectal cancer by balancing the level of miR-25-3p [137]. Silencing target genes using siRNA is another way to inhibit tumor growth. As overexpression of polo-like kinase (PLK)-1 is associated with the development of bladder cancer, one study showed that treatment with PLK-1 siRNA containing exosomes inhibited bladder cancer growth [138]. Similarly, as GRP78 overexpression is implicated in the growth and metastasis of hepatocellular carcinoma, treatment with GRP78 siRNA expressing exosomes resulted in an efficacious antitumor response in a sorafenib-resistant hepatocellular carcinoma model [139]. HSP27, a member of the heat-shock protein family, is known to promote neuron maturation and can be involved in the development of neuroblastoma. Treatment with Hsp27 siRNA-tagged exosome showed a significant reduction in tumor growth of the neuroblastoma cell line SH-SY5Y [140]. mRNA can be another candidate for anticancer therapy using exosome vehicles. Transferring CRISPR-associated protein (Cas) 9 mRNA-expressing exosomes from red blood cells induced miRNA inhibition and Cas9 genome editing effects in a breast cancer model [141]. Phosphatase and tensin homolog (PTEN) and esophageal cancer-related gene (ECRG) 4 are classified as tumor suppressors and are generally mutated in cancer cells. Therefore, treatment with exosomes expressing PTEN or ECRG4 mRNA could inhibit the growth of glioma cells [145] and tongue squamous cell carcinoma cells, respectively [143]. These studies show that depending on the target, different types of RNA therapeutics can be chosen, and the therapeutic efficacy of these drugs can be substantially enhanced by using exosomes as delivery vehicles.

\subsection{Exosomes into Personalized Cancer Immunotherapy Drug Design (Single or in Combination)}

Exosomes can be used as cell-free vaccines owing to the fact that exosomes derived from various donor cells, such as immune cells and cancer cells, are involved in fostering antitumor immunity [146]. DEXs can perform important immunostimulatory functions, as DCs that act as sentinel antigen-presenting cells play a crucial role in orchestrating cancer-specific adaptive immunity [147]. The surface of DEXs is characterized by various functional molecules for priming T cells such as MHC class I/II and costimulatory molecules including CD40, CD80, and CD86 [148]. This can foster antitumor 
immunity by inducing the activation of both innate and adaptive immunity. In several preclinical tests, treating DEXs could elicit antitumor effects and prolong the survival rate of tumor-bearing mice by expanding the repertoire of tumor-specific cytotoxic T cells as well as activating naïve T cells [149]. DEXs are also known to induce NK cell-mediated cytotoxicity to inhibit tumor growth [150]. In order to potentiate the efficacy of DEX as a therapeutic cancer vaccine, choosing an appropriate TAA and a relevant adjuvant is essential. To date, both for human and preclinical studies, only MHC class I/II binding peptides such as Epstein-Barr virus, melanoma-associated antigen, and melanoma antigen recognized by T cells- 1 have been used for DEX vaccine $[13,14,151]$. However, the use of peptide-based DEX vaccine was not very effective in inducing antitumor effects due to modest activation of antitumor immune responses [152]. Several studies have reported that a more intense adaptive immune response can be induced with a DEX vaccine loaded with protein antigen [152,153]. This effect might be attributable to the presence of a broad range of epitopes with protein antigens, which might be more effective in activating various repertoires of tumor-specific cytotoxic T cells. These studies demonstrate the ability of personalized DEX vaccines based on patient tumor lysates. Therefore, a more potent DEX vaccine that can evoke strong antigen-specific responses can be manufactured with the loading of an allogenic protein antigen. Based on other studies, B cells are required to boost antitumor immunity, suggesting that epitopes, which activate B cells, are also needed for a successful DEX vaccine $[152,153]$. These results also provide a rationale for utilizing personalized protein antigens as cargo in DEX vaccines. General adjuvants such as interferon- $\gamma$ and toll-like receptor agonists, including polyinosinic:polycytidylic acid and CpG oligodeoxynucleotides can be used to potentiate the efficacy of DEX vaccine. It is also known that the use of these adjuvants can result in the maturation of DCs and ultimately produce more immunogenic DEXs [154]. DEXs derived from mature DCs are known to express more costimulatory surface molecules including CD40, CD80, CD86, and intercellular adhesion molecule -1 and MHC class I/II [149]. Even though the DEX vaccine seems to show promising outcomes, several challenges remain until it can be widely used in clinics, as the research on this therapy is still at an early stage. For example, it is not clear whether the mass production of personalized DEX vaccine possessing a homogenous quality is available. At present, there are no clear guidelines regarding the production of exosome-based therapeutics. Proper storage, maintenance of stability, and route of administration for exosomes are also the issues to be considered [155].

Besides, CAR exosomes derived from effector CAR-T cells showed cytotoxic effects on cancer cells [156]. Intravenous injection of CAR exosomes into a mouse xenograft model exerted potent tumor growth inhibition. A combination of exosomal therapy with other immunotherapies such as immune-checkpoint blockers, cytokines, adoptive $\mathrm{T}$ cell transfer, and cancer vaccines might be a good way to elicit synergistic anticancer effects. For the combined utilization of CAR exosomes and CAR-T cells, further clinical/preclinical studies are required, and the clinically applicable scheme should be proposed.

\section{Conclusions and Future Perspectives}

Recently, cancer therapeutics has made great strides, and various clinical trials for targeted cancer therapy or immunotherapy have been conducted singly or in combination. However, there remains an unmet need, because only a few types of cancer patients are restrictedly responsive to current immune checkpoint blockers. In order to elevate response rate for personalized immunotherapy, prognostic biomarkers need to be established. As mentioned above, exosomal components can be used as diagnostic biomarkers in liquid biopsy, nanovehicles for delivery of anticancer drugs, and mediators between cells affecting tumor immunity. Detection of marker proteins or nucleic acids in circulating exosomes shows potential for predicting patients' clinical response [157]. "TEXs-on-chip" techniques using patient-derived tumor spheroids obtained from liquid biopsy will be applicable in the near future.

In that vaccinating autologous exosomes obtained from patients can avoid allograft reaction and carry tumor antigens, patient-derived exosomes have received attention as good candidates for personalized immunotherapy. Using bone marrow aspirate from patients, MSCs are isolated and 
expanded ex vivo, and then large scale of MSCs engineered with anticancer genes can be transplanted to patients for personalized treatment [158]. As exosomes released from MSCs acquire tropism toward tumor locations and the corresponding receptors with the original MSC, they would mediate anticancer activity [159]. Engineering techniques for enhancing therapeutic efficacy of these cell-free vaccines are needed for the development of innovative personalized immunotherapy.

Author Contributions: Conceptualization, J.U.C. and S.R.H.; methodology and validation, I.-K.P.; investigation, J.U.C.; writing - Original draft preparation, J.U.C.; writing - Review and editing, S.R.H.; visualization, Y.-K.L.; supervision, I.-K.P.; funding acquisition, Y.-K.L. and S.R.H. All authors have read and agreed to the published version of the manuscript.

Funding: This research was supported by the National Research Foundation of Korea (NRF) grant funded by the Ministry of Science and ICT (grant numbers NRF-2019R1F1A1057702, NRF-2019R1A4A1024116 and NRF-2018R1D1A1A09083269).

Acknowledgments: The authors acknowledge KB BIOMED Inc. for administrative and technical support.

Conflicts of Interest: The authors declare no conflict of interest.

\section{Abbreviations}

$\begin{array}{ll}\text { ADC } & \text { Antibody-drug conjugate } \\ \text { ALIX } & \text { Apoptosis-linked gene 2-interacting protein X } \\ \text { ALK } & \text { Anaplastic lymphoma kinase } \\ \text { CAF } & \text { Cancer-associated fibroblasts } \\ \text { CAR } & \text { Chimeric antigen receptor } \\ \text { Cas } & \text { CRISPR-associated protein } \\ \text { CD } & \text { Cytosine deaminase } \\ \text { CSF1R } & \text { Colony-stimulating factor-1 receptor } \\ \text { CTC } & \text { Circulating-tumor cell } \\ \text { ctDNA } & \text { Circulating tumor DNA } \\ \text { CTLA4 } & \text { Cytotoxic T-lymphocyte-associated protein } 4 \\ \text { DC } & \text { Dendritic cell } \\ \text { DEX } & \text { Dendritic cell-derived exosome } \\ \text { ECM } & \text { Extracellular matrix } \\ \text { ECRG } & \text { Esophageal cancer-related gene } \\ \text { EGFR } & \text { Epidermal growth factor receptor } \\ \text { EpCAM } & \text { Epithelial cell adhesion molecule } \\ \text { ER } & \text { Endoplasmic reticulum } \\ \text { ESCRT } & \text { Endosomal sorting complex required for transport } \\ \text { EV } & \text { Extracellular vesicle } \\ \text { FGFR } & \text { Fibroblast growth factor receptor } \\ \text { FLT3 } & \text { FMS-like tyrosine kinase 3 } \\ \text { GM-CSF } & \text { Granulocyte-macrophage colony-stimulating factor } \\ \text { GPI } & \text { Glycosylphosphatidylinositol } \\ \text { HRS } & \text { Hepatocyte growth factor-regulated tyrosine kinase substrate } \\ \text { HSP } & \text { Heat shock protein } \\ \text { ICAM } & \text { Intercellular adhesion molecule } \\ \text { ILV } & \text { Intraluminal vesicle } \\ \text { KLF } & \text { Kruppel-like factor } \\ \text { lncRNA } & \text { Long non-coding RNA } \\ \text { MHC } & \text { Major histocompatibility complex } \\ \text { miRNA } & \text { MicroRNA } \\ \text { MMP } & \text { Matrix metalloproteinase } \\ \text { mRNA } & \text { Messenger RNA } \\ \text { MSC } & \text { Mesenchymal stem cell } \\ \text { MV } & \text { Microvesicle } \\ \text { MVB } & \text { Multivesicular body } \\ & \end{array}$




$\begin{array}{ll}\text { NGS } & \text { Next-generation sequencing } \\ \text { NK } & \text { Natural killer } \\ \text { NSCLC } & \text { Non-small cell lung cancer } \\ \text { NTRK } & \text { Neurotrophic tyrosine receptor kinase } \\ \text { PCR } & \text { Polymerase chain reaction } \\ \text { PD-1 } & \text { Programmed cell death protein 1 } \\ \text { PD-L1 } & \text { Programmed cell death ligand 1 } \\ \text { PLK } & \text { Polo-like kinase } \\ \text { PTEN } & \text { Phosphatase and tensin homolog } \\ \text { ROS1 } & \text { C-ros oncogene 1 } \\ \text { RTK } & \text { Receptor tyrosine kinase } \\ \text { siRNA } & \text { Small interfering RNA } \\ \text { SIRP } & \text { Signal-regulatory protein } \\ \text { TAA } & \text { Tumor-associated antigen } \\ \text { TEX } & \text { Tumor-derived exosome } \\ \text { TMZ } & \text { Temozolomide } \\ \text { TRAIL } & \text { TNF-related apoptosis-inducing ligand } \\ \text { TRIM } & \text { Tripartite motif-containing protein } \\ \text { UPRT } & \text { Uracil phosphoribosyltransferase }\end{array}$

\section{References}

1. Mullard, A. 2019 FDA drug approvals. Nat. Rev. Drug Discov. 2020, 19, 79-84. [CrossRef] [PubMed]

2. Zhang, Y.; Li, M.; Gao, X.; Chen, Y.; Liu, T. Nanotechnology in cancer diagnosis: Progress, challenges and opportunities. J. Hematol. Oncol. 2019, 12, 137. [CrossRef] [PubMed]

3. Jeon, S.M.; Kwon, J.W.; Choi, S.H.; Park, H.Y. Economic burden of lung cancer: A retrospective cohort study in South Korea, 2002-2015. PLoS ONE 2019, 14, e0212878. [CrossRef] [PubMed]

4. Yang, Y.; Miller, C.R.; Lopez-Beltran, A.; Montironi, R.; Cheng, M.; Zhang, S.; Koch, M.O.; Kaimakliotis, H.Z.; Cheng, L. Liquid Biopsies in the Management of Bladder Cancer: Next-Generation Biomarkers for Diagnosis, Surveillance, and Treatment-Response Prediction. Crit. Rev. Oncog. 2017, 22, 389-401. [CrossRef]

5. Melo, S.A.; Sugimoto, H.; O'Connell, J.T.; Kato, N.; Villanueva, A.; Vidal, A.; Qiu, L.; Vitkin, E.; Perelman, L.T.; Melo, C.A.; et al. Cancer exosomes perform cell-independent microRNA biogenesis and promote tumorigenesis. Cancer Cell 2014, 26, 707-721. [CrossRef]

6. Kamerkar, S.; LeBleu, V.S.; Sugimoto, H.; Yang, S.; Ruivo, C.F.; Melo, S.A.; Lee, J.J.; Kalluri, R. Exosomes facilitate therapeutic targeting of oncogenic KRAS in pancreatic cancer. Nature 2017, 546, 498-503. [CrossRef]

7. Jan, M.; Majeti, R. Clonal evolution of acute leukemia genomes. Oncogene 2013, 32, 135-140. [CrossRef]

8. Turner, N.C.; Reis-Filho, J.S. Genetic heterogeneity and cancer drug resistance. Lancet. Oncol. 2012, 13, e178-e185. [CrossRef]

9. Waldmann, T.A. Immunotherapy: Past, present and future. Nat. Med. 2003, 9, 269-277. [CrossRef]

10. Chauhan, V.P.; Stylianopoulos, T.; Boucher, Y.; Jain, R.K. Delivery of molecular and nanoscale medicine to tumors: Transport barriers and strategies. Annu. Rev. Chem. Biomol. Eng. 2011, 2, 281-298. [CrossRef]

11. Au, J.L.; Yeung, B.Z.; Wientjes, M.G.; Lu, Z.; Wientjes, M.G. Delivery of cancer therapeutics to extracellular and intracellular targets: Determinants, barriers, challenges and opportunities. Adv. Drug. Deliv. Rev. 2016, 97, 280-301. [CrossRef] [PubMed]

12. Mendez-Ferrer, S.; Bonnet, D.; Steensma, D.P.; Hasserjian, R.P.; Ghobrial, I.M.; Gribben, J.G.; Andreeff, M.; Krause, D.S. Bone marrow niches in haematological malignancies. Nat. Rev. Cancer 2020, 20, 285-298. [CrossRef] [PubMed]

13. Escudier, B.; Dorval, T.; Chaput, N.; Andre, F.; Caby, M.P.; Novault, S.; Flament, C.; Leboulaire, C.; Borg, C.; Amigorena, S.; et al. Vaccination of metastatic melanoma patients with autologous dendritic cell (DC) derived-exosomes: Results of thefirst phase I clinical trial. J Transl. Med. 2005, 3, 10. [CrossRef] [PubMed]

14. Morse, M.A.; Garst, J.; Osada, T.; Khan, S.; Hobeika, A.; Clay, T.M.; Valente, N.; Shreeniwas, R.; Sutton, M.A.; Delcayre, A.; et al. A phase I study of dexosome immunotherapy in patients with advanced non-small cell lung cancer. J. Transl. Med. 2005, 3, 9. [CrossRef] [PubMed]

15. Dai, S.; Wei, D.; Wu, Z.; Zhou, X.; Wei, X.; Huang, H.; Li, G. Phase I clinical trial of autologous ascites-derived exosomes combined with GM-CSF for colorectal cancer. Mol. Ther. 2008, 16, 782-790. [CrossRef] [PubMed] 
16. Hessvik, N.P.; Llorente, A. Current knowledge on exosome biogenesis and release. Cell Mol. Life Sci. 2018, 75, 193-208. [CrossRef]

17. Huotari, J.; Helenius, A. Endosome maturation. EMBO J. 2011, 30, 3481-3500. [CrossRef]

18. Raposo, G.; Stoorvogel, W. Extracellular vesicles: Exosomes, microvesicles, and friends. J. Cell Biol. 2013, 200, 373-383. [CrossRef]

19. Wollert, T.; Hurley, J.H. Molecular mechanism of multivesicular body biogenesis by ESCRT complexes. Nature 2010, 464, 864-869. [CrossRef]

20. Henne, W.M.; Stenmark, H.; Emr, S.D. Molecular mechanisms of the membrane sculpting ESCRT pathway. Cold Spring Harb. Perspect. Biol. 2013, 5, a016766. [CrossRef]

21. Glickman, M.H.; Ciechanover, A. The ubiquitin-proteasome proteolytic pathway: Destruction for the sake of construction. Physiol. Rev. 2002, 82, 373-428. [CrossRef]

22. Mani, A.; Gelmann, E.P. The ubiquitin-proteasome pathway and its role in cancer. J. Clin. Oncol. 2005, 23, 4776-4789. [CrossRef]

23. Clifford, S.C.; Cockman, M.E.; Smallwood, A.C.; Mole, D.R.; Woodward, E.R.; Maxwell, P.H.; Ratcliffe, P.J.; Maher, E.R. Contrasting effects on HIF-1alpha regulation by disease-causing $\mathrm{pVHL}$ mutations correlate with patterns of tumourigenesis in von Hippel-Lindau disease. Hum. Mol. Genet. 2001, 10, 1029-1038. [CrossRef]

24. Hashizume, R.; Fukuda, M.; Maeda, I.; Nishikawa, H.; Oyake, D.; Yabuki, Y.; Ogata, H.; Ohta, T. The RING heterodimer BRCA1-BARD1 is a ubiquitin ligase inactivated by a breast cancer-derived mutation. J. Biol. Chem. 2001, 276, 14537-14540. [CrossRef] [PubMed]

25. Stuffers, S.; Sem Wegner, C.; Stenmark, H.; Brech, A. Multivesicular endosome biogenesis in the absence of ESCRTs. Traffic 2009, 10, 925-937. [CrossRef] [PubMed]

26. Wubbolts, R.; Leckie, R.S.; Veenhuizen, P.T.; Schwarzmann, G.; Mobius, W.; Hoernschemeyer, J.; Slot, J.W.; Geuze, H.J.; Stoorvogel, W. Proteomic and biochemical analyses of human B cell-derived exosomes. Potential implications for their function and multivesicular body formation. J. Biol. Chem. 2003, 278, 10963-10972. [CrossRef]

27. Trajkovic, K.; Hsu, C.; Chiantia, S.; Rajendran, L.; Wenzel, D.; Wieland, F.; Schwille, P.; Brugger, B.; Simons, M. Ceramide triggers budding of exosome vesicles into multivesicular endosomes. Science 2008, 319, 1244-1247. [CrossRef] [PubMed]

28. Mobius, W.; Ohno-Iwashita, Y.; van Donselaar, E.G.; Oorschot, V.M.; Shimada, Y.; Fujimoto, T.; Heijnen, H.F.; Geuze, H.J.; Slot, J.W. Immunoelectron microscopic localization of cholesterol using biotinylated and non-cytolytic perfringolysin O. J. Histochem. Cytochem. 2002, 50, 43-55. [CrossRef]

29. Baietti, M.F.; Zhang, Z.; Mortier, E.; Melchior, A.; Degeest, G.; Geeraerts, A.; Ivarsson, Y.; Depoortere, F.; Coomans, C.; Vermeiren, E.; et al. Syndecan-syntenin-ALIX regulates the biogenesis of exosomes. Nat. Cell Biol. 2012, 14, 677-685. [CrossRef]

30. Geminard, C.; De Gassart, A.; Blanc, L.; Vidal, M. Degradation of AP2 during reticulocyte maturation enhances binding of hsc70 and Alix to a common site on TFR for sorting into exosomes. Traffic 2004, 5, 181-193. [CrossRef]

31. Tamai, K.; Tanaka, N.; Nakano, T.; Kakazu, E.; Kondo, Y.; Inoue, J.; Shiina, M.; Fukushima, K.; Hoshino, T.; Sano, K.; et al. Exosome secretion of dendritic cells is regulated by Hrs, an ESCRT-0 protein. Biochem. Biophys. Res. Commun. 2010, 399, 384-390. [CrossRef] [PubMed]

32. Batagov, A.O.; Kuznetsov, V.A.; Kurochkin, I.V. Identification of nucleotide patterns enriched in secreted RNAs as putative cis-acting elements targeting them to exosome nano-vesicles. BMC Genomics. 2011, 12, S3-S18. [CrossRef] [PubMed]

33. Gibbings, D.J.; Ciaudo, C.; Erhardt, M.; Voinnet, O. Multivesicular bodies associate with components of miRNA effector complexes and modulate miRNA activity. Nat. Cell. Biol. 2009, 11, 1143-1149. [CrossRef] [PubMed]

34. Spaull, R.; McPherson, B.; Gialeli, A.; Clayton, A.; Uney, J.; Heep, A.; Cordero-Llana, O. Exosomes populate the cerebrospinal fluid of preterm infants with post-haemorrhagic hydrocephalus. Int J. Dev. Neurosci. 2019, 73, 59-65. [CrossRef] [PubMed]

35. Huleihel, L.; Hussey, G.S.; Naranjo, J.D.; Zhang, L.; Dziki, J.L.; Turner, N.J.; Stolz, D.B.; Badylak, S.F. Matrix-bound nanovesicles within ECM bioscaffolds. Sci. Adv. 2016, 2, e1600502. [CrossRef] 
36. Zhuang, X.; Xiang, X.; Grizzle, W.; Sun, D.; Zhang, S.; Axtell, R.C.; Ju, S.; Mu, J.; Zhang, L.; Steinman, L. Treatment of brain inflammatory diseases by delivering exosome encapsulated anti-inflammatory drugs from the nasal region to the brain. Mol. Ther. 2011, 19, 1769-1779. [CrossRef]

37. Sung, B.H.; von Lersner, A.; Guerrero, J.; Krystofiak, E.S.; Inman, D.; Pelletier, R.; Zijlstra, A.; Ponik, S.M.; Weaver, A.M. A live cell reporter of exosome secretion and uptake reveals pathfinding behavior of migrating cells. Nat. Commun. 2020, 11, 2092. [CrossRef]

38. Tian, T.; Zhu, Y.L.; Zhou, Y.Y.; Liang, G.F.; Wang, Y.Y.; Hu, F.H.; Xiao, Z.D. Exosome uptake through clathrin-mediated endocytosis and macropinocytosis and mediating miR-21 delivery. J. Biol. Chem. 2014, 289, 22258-22267. [CrossRef]

39. Fitzner, D.; Schnaars, M.; van Rossum, D.; Krishnamoorthy, G.; Dibaj, P.; Bakhti, M.; Regen, T.; Hanisch, U.K.; Simons, M. Selective transfer of exosomes from oligodendrocytes to microglia by macropinocytosis. J. Cell Sci. 2011, 124, 447-458. [CrossRef]

40. Nanbo, A.; Kawanishi, E.; Yoshida, R.; Yoshiyama, H. Exosomes derived from Epstein-Barr virus-infected cells are internalized via caveola-dependent endocytosis and promote phenotypic modulation in target cells. J. Virol. 2013, 87, 10334-10347. [CrossRef]

41. Valapala, M.; Vishwanatha, J.K. Lipid raft endocytosis and exosomal transport facilitate extracellular trafficking of annexin A2. J. Biol. Chem. 2011, 286, 30911-30925. [CrossRef] [PubMed]

42. Bonsergent, E.; Lavieu, G. Content release of extracellular vesicles in a cell-free extract. FEBS Lett. 2019, 593, 1983-1992. [CrossRef] [PubMed]

43. Mincheva-Nilsson, L.; Baranov, V. Cancer exosomes and NKG2D receptor-ligand interactions: Impairing NKG2D-mediated cytotoxicity and anti-tumour immune surveillance. Semin. Cancer Biol. 2014, 28, 24-30. [CrossRef]

44. Thery, C.; Zitvogel, L.; Amigorena, S. Exosomes: Composition, biogenesis and function. Nat. Rev. Immunol. 2002, 2, 569-579. [CrossRef] [PubMed]

45. Imai, T.; Takahashi, Y.; Nishikawa, M.; Kato, K.; Morishita, M.; Yamashita, T.; Matsumoto, A.; Charoenviriyakul, C.; Takakura, Y. Macrophage-dependent clearance of systemically administered B16BL6-derived exosomes from the blood circulation in mice. J. Extracell. Vesicles 2015, 4, 26238. [CrossRef]

46. Maas, S.L.N.; Breakefield, X.O.; Weaver, A.M. Extracellular Vesicles: Unique Intercellular Delivery Vehicles. Trends. Cell Biol. 2017, 27, 172-188. [CrossRef] [PubMed]

47. Oushy, S.; Hellwinkel, J.E.; Wang, M.; Nguyen, G.J.; Gunaydin, D.; Harland, T.A.; Anchordoquy, T.J.; Graner, M.W. Glioblastoma multiforme-derived extracellular vesicles drive normal astrocytes towards a tumour-enhancing phenotype. Philos. Trans. R. Soc. Lond. B. Biol. Sci. 2018, 373, 200160477. [CrossRef]

48. Syn, N.; Wang, L.; Sethi, G.; Thiery, J.P.; Goh, B.C. Exosome-Mediated Metastasis: From Epithelial-Mesenchymal Transition to Escape from Immunosurveillance. Trends. Pharmacol. Sci. 2016, 37, 606-617. [CrossRef]

49. Sato, S.; Weaver, A.M. Extracellular vesicles: Important collaborators in cancer progression. Essays. Biochem. 2018, 62, 149-163.

50. Hoshino, D.; Kirkbride, K.C.; Costello, K.; Clark, E.S.; Sinha, S.; Grega-Larson, N.; Tyska, M.J.; Weaver, A.M. Exosome secretion is enhanced by invadopodia and drives invasive behavior. Cell Rep. 2013, 5, 1159-1168. [CrossRef]

51. Baroni, S.; Romero-Cordoba, S.; Plantamura, I.; Dugo, M.; D'ippolito, E.; Cataldo, A.; Cosentino, G.; Angeloni, V.; Rossini, A.; Daidone, M. Exosome-mediated delivery of miR-9 induces cancer-associated fibroblast-like properties in human breast fibroblasts. Cell Death Dis. 2016, 7, e2312. [CrossRef] [PubMed]

52. Webber, J.P.; Spary, L.K.; Sanders, A.J.; Chowdhury, R.; Jiang, W.G.; Steadman, R.; Wymant, J.; Jones, A.T.; Kynaston, H.; Mason, M.D.; et al. Differentiation of tumour-promoting stromal myofibroblasts by cancer exosomes. Oncogene 2015, 34, 290-302. [CrossRef] [PubMed]

53. Webber, J.; Steadman, R.; Mason, M.D.; Tabi, Z.; Clayton, A. Cancer exosomes trigger fibroblast to myofibroblast differentiation. Cancer Res. 2010, 70, 9621-9630. [CrossRef] [PubMed]

54. Luga, V.; Zhang, L.; Viloria-Petit, A.M.; Ogunjimi, A.A.; Inanlou, M.R.; Chiu, E.; Buchanan, M.; Hosein, A.N.; Basik, M.; Wrana, J.L. Exosomes mediate stromal mobilization of autocrine Wnt-PCP signaling in breast cancer cell migration. Cell 2012, 151, 1542-1556. [CrossRef] [PubMed] 
55. Shimoda, M.; Principe, S.; Jackson, H.W.; Luga, V.; Fang, H.; Molyneux, S.D.; Shao, Y.W.; Aiken, A.; Waterhouse, P.D.; Karamboulas, C. Loss of the Timp gene family is sufficient for the acquisition of the CAF-like cell state. Nat. Cell Biol. 2014, 16, 889-901. [CrossRef] [PubMed]

56. Lazar, I.; Clement, E.; Dauvillier, S.; Milhas, D.; Ducoux-Petit, M.; LeGonidec, S.; Moro, C.; Soldan, V.; Dalle, S.; Balor, S. Adipocyte exosomes promote melanoma aggressiveness through fatty acid oxidation: A novel mechanism linking obesity and cancer. Cancer Res. 2016, 76, 4051-4057. [CrossRef] [PubMed]

57. Ribeiro, M.F.; Zhu, H.; Millard, R.W.; Fan, G.C. Exosomes Function in Pro- and Anti-Angiogenesis. Curr. Angiogenes 2013, 2, 54-59.

58. Carrasco-Ramírez, P.; Greening, D.W.; Andrés, G.; Gopal, S.K.; Martín-Villar, E.; Renart, J.; Simpson, R.J.; Quintanilla, M. Podoplanin is a component of extracellular vesicles that reprograms cell-derived exosomal proteins and modulates lymphatic vessel formation. Oncotarget 2016, 7, 16070. [CrossRef]

59. Umezu, T.; Ohyashiki, K.; Kuroda, M.; Ohyashiki, J. Leukemia cell to endothelial cell communication via exosomal miRNAs. Oncogene 2013, 32, 2747-2755. [CrossRef]

60. Schillaci, O.; Fontana, S.; Monteleone, F.; Taverna, S.; Di Bella, M.A.; Di Vizio, D.; Alessandro, R. Exosomes from metastatic cancer cells transfer amoeboid phenotype to non-metastatic cells and increase endothelial permeability: Their emerging role in tumor heterogeneity. Sci. Rep. 2017, 7, 1-15. [CrossRef]

61. Hsu, Y.L.; Hung, J.Y.; Chang, W.A.; Lin, Y.S.; Pan, Y.C.; Tsai, P.H.; Wu, C.Y.; Kuo, P.L. Hypoxic lung cancer-secreted exosomal miR-23a increased angiogenesis and vascular permeability by targeting prolyl hydroxylase and tight junction protein ZO-1. Oncogene 2017, 36, 4929-4942. [CrossRef] [PubMed]

62. Liu, Y.; Cao, X. Characteristics and Significance of the Pre-metastatic Niche. Cancer Cell 2016, 30, 668-681. [CrossRef] [PubMed]

63. Peinado, H.; Alečković, M.; Lavotshkin, S.; Matei, I.; Costa-Silva, B.; Moreno-Bueno, G.; Hergueta-Redondo, M.; Williams, C.; García-Santos, G.; Ghajar, C.M. Melanoma exosomes educate bone marrow progenitor cells toward a pro-metastatic phenotype through MET. Nat. Med. 2012, 18, 883-891. [CrossRef] [PubMed]

64. Costa-Silva, B.; Aiello, N.M.; Ocean, A.J.; Singh, S.; Zhang, H.; Thakur, B.K.; Becker, A.; Hoshino, A.; Mark, M.T.; Molina, H. Pancreatic cancer exosomes initiate pre-metastatic niche formation in the liver. Nat. cell Biol. 2015, 17, 816-826. [CrossRef]

65. Hoshino, A.; Costa-Silva, B.; Shen, T.-L.; Rodrigues, G.; Hashimoto, A.; Mark, M.T.; Molina, H.; Kohsaka, S.; Di Giannatale, A.; Ceder, S. Tumour exosome integrins determine organotropic metastasis. Nature 2015, 527, 329-335. [CrossRef]

66. Hood, J.L.; San, R.S.; Wickline, S.A. Exosomes released by melanoma cells prepare sentinel lymph nodes for tumor metastasis. Cancer Res. 2011, 71, 3792-3801. [CrossRef]

67. Plebanek, M.P.; Angeloni, N.L.; Vinokour, E.; Li, J.; Henkin, A.; Martinez-Marin, D.; Filleur, S.; Bhowmick, R.; Henkin, J.; Miller, S.D.; et al. Pre-metastatic cancer exosomes induce immune surveillance by patrolling monocytes at the metastatic niche. Nat. Commun. 2017, 8, 1319. [CrossRef]

68. Whiteside, T.L. Exosomes and tumor-mediated immune suppression. J. Clin. Investig. 2016, 126, 1216-1223. [CrossRef]

69. Clayton, A.; Mitchell, J.P.; Court, J.; Mason, M.D.; Tabi, Z. Human tumor-derived exosomes selectively impair lymphocyte responses to interleukin-2. Cancer Res. 2007, 67, 7458-7466. [CrossRef]

70. Clayton, A.; Mitchell, J.P.; Court, J.; Linnane, S.; Mason, M.D.; Tabi, Z. Human tumor-derived exosomes down-modulate NKG2D expression. J. Immunol. 2008, 180, 7249-7258. [CrossRef]

71. Zitvogel, L.; Regnault, A.; Lozier, A.; Wolfers, J.; Flament, C.; Tenza, D.; Ricciardi-Castagnoli, P.; Raposo, G.; Amigorena, S. Eradication of established murine tumors using a novel cell-free vaccine: Dendritic cell-derived exosomes. Nat. Med. 1998, 4, 594-600. [CrossRef] [PubMed]

72. Skokos, D.; Botros, H.G.; Demeure, C.; Morin, J.; Peronet, R.; Birkenmeier, G.; Boudaly, S.; Mecheri, S. Mast cell-derived exosomes induce phenotypic and functional maturation of dendritic cells and elicit specific immune responses in vivo. J. Immunol. 2003, 170, 3037-3045. [CrossRef] [PubMed]

73. Chen, W.X.; Liu, X.M.; Lv, M.M.; Chen, L.; Zhao, J.H.; Zhong, S.L.; Ji, M.H.; Hu, Q.; Luo, Z.; Wu, J.Z.; et al. Exosomes from drug-resistant breast cancer cells transmit chemoresistance by a horizontal transfer of microRNAs. PLoS ONE 2014, 9, e95240. [CrossRef] [PubMed] 
74. Zeng, A.; Wei, Z.; Yan, W.; Yin, J.; Huang, X.; Zhou, X.; Li, R.; Shen, F.; Wu, W.; Wang, X. Exosomal transfer of miR-151a enhances chemosensitivity to temozolomide in drug-resistant glioblastoma. Cancer Lett. 2018, 436, 10-21. [CrossRef] [PubMed]

75. Federici, C.; Petrucci, F.; Caimi, S.; Cesolini, A.; Logozzi, M.; Borghi, M.; D’Ilio, S.; Lugini, L.; Violante, N.; Azzarito, T.; et al. Exosome release and low $\mathrm{pH}$ belong to a framework of resistance of human melanoma cells to cisplatin. PLoS ONE 2014, 9, e88193. [CrossRef] [PubMed]

76. Hu, Y.; Yan, C.; Mu, L.; Huang, K.; Li, X.; Tao, D.; Wu, Y.; Qin, J. Fibroblast-Derived Exosomes Contribute to Chemoresistance through Priming Cancer Stem Cells in Colorectal Cancer. PLoS ONE 2015, 10, e0125625. [CrossRef]

77. Boelens, M.C.; Wu, T.J.; Nabet, B.Y.; Xu, B.; Qiu, Y.; Yoon, T.; Azzam, D.J.; Twyman-Saint Victor, C.; Wiemann, B.Z.; Ishwaran, H.; et al. Exosome transfer from stromal to breast cancer cells regulates therapy resistance pathways. Cell 2014, 159, 499-513. [CrossRef]

78. Thery, C.; Amigorena, S.; Raposo, G.; Clayton, A. Isolation and characterization of exosomes from cell culture supernatants and biological fluids. Curr. Protoc. Cell Biol. 2006, 30, 3.22.1-3.22.29. [CrossRef]

79. Tauro, B.J.; Greening, D.W.; Mathias, R.A.; Ji, H.; Mathivanan, S.; Scott, A.M.; Simpson, R.J. Comparison of ultracentrifugation, density gradient separation, and immunoaffinity capture methods for isolating human colon cancer cell line LIM1863-derived exosomes. Methods 2012, 56, 293-304. [CrossRef]

80. Taylor, D.D.; Shah, S. Methods of isolating extracellular vesicles impact down-stream analyses of their cargoes. Methods 2015, 87, 3-10. [CrossRef]

81. Riahi, R.; Shaegh, S.A.; Ghaderi, M.; Zhang, Y.S.; Shin, S.R.; Aleman, J.; Massa, S.; Kim, D.; Dokmeci, M.R.; Khademhosseini, A. Automated microfluidic platform of bead-based electrochemical immunosensor integrated with bioreactor for continual monitoring of cell secreted biomarkers. Sci. Rep. 2016, 6, 24598. [CrossRef] [PubMed]

82. Kaddour, H.; Lyu, Y.; Shouman, N.; Mohan, M.; Okeoma, C.M. Development of Novel High-Resolution Size-Guided Turbidimetry-Enabled Particle Purification Liquid Chromatography (PPLC): Extracellular Vesicles and Membraneless Condensates in Focus. Int. J. Mol. Sci 2020, 21, 5361. [CrossRef] [PubMed]

83. Doldan, X.; Fagundez, P.; Cayota, A.; Laiz, J.; Tosar, J.P. Electrochemical Sandwich Immunosensor for Determination of Exosomes Based on Surface Marker-Mediated Signal Amplification. Anal. Chem. 2016, 88, 10466-10473. [CrossRef] [PubMed]

84. Miller, M.C.; Doyle, G.V.; Terstappen, L.W. Significance of Circulating Tumor Cells Detected by the CellSearch System in Patients with Metastatic Breast Colorectal and Prostate Cancer. J. Oncol. 2010, 2010, 617421. [CrossRef] [PubMed]

85. Yu, M.; Stott, S.; Toner, M.; Maheswaran, S.; Haber, D.A. Circulating tumor cells: Approaches to isolation and characterization. J. Cell Biol. 2011, 192, 373-382. [CrossRef]

86. Wan, J.C.M.; Massie, C.; Garcia-Corbacho, J.; Mouliere, F.; Brenton, J.D.; Caldas, C.; Pacey, S.; Baird, R.; Rosenfeld, N. Liquid biopsies come of age: Towards implementation of circulating tumour DNA. Nat. Rev. Cancer 2017, 17, 223-238. [CrossRef] [PubMed]

87. Heitzer, E.; Ulz, P.; Geigl, J.B. Circulating tumor DNA as a liquid biopsy for cancer. Clin. Chem. 2015, 61, 112-123. [CrossRef]

88. Figueroa, J.M.; Skog, J.; Akers, J.; Li, H.; Komotar, R.; Jensen, R.; Ringel, F.; Yang, I.; Kalkanis, S.; Thompson, R.; et al. Detection of wild-type EGFR amplification and EGFRvIII mutation in CSF-derived extracellular vesicles of glioblastoma patients. Neuro. Oncol. 2017, 19, 1494-1502. [CrossRef]

89. Pisitkun, T.; Shen, R.F.; Knepper, M.A. Identification and proteomic profiling of exosomes in human urine. Proc. Natl. Acad. Sci. USA 2004, 101, 13368-13373. [CrossRef]

90. Chung, I.M.; Rajakumar, G.; Venkidasamy, B.; Subramanian, U.; Thiruvengadam, M. Exosomes: Current use and future applications. Clin. Chim. Acta. 2020, 500, 226-232. [CrossRef]

91. Jalalian, S.H.; Ramezani, M.; Jalalian, S.A.; Abnous, K.; Taghdisi, S.M. Exosomes, new biomarkers in early cancer detection. Anal. Biochem. 2019, 571, 1-13. [CrossRef] [PubMed]

92. Logozzi, M.; De Milito, A.; Lugini, L.; Borghi, M.; Calabro, L.; Spada, M.; Perdicchio, M.; Marino, M.L.; Federici, C.; Iessi, E.; et al. High levels of exosomes expressing CD63 and caveolin-1 in plasma of melanoma patients. PLoS ONE 2009, 4, e5219. [CrossRef] [PubMed] 
93. Qu, J.L.; Qu, X.J.; Zhao, M.F.; Teng, Y.E.; Zhang, Y.; Hou, K.Z.; Jiang, Y.H.; Yang, X.H.; Liu, Y.P. Gastric cancer exosomes promote tumour cell proliferation through PI3K/Akt and MAPK/ERK activation. Dig. Liver. Dis. 2009, 41, 875-880. [CrossRef] [PubMed]

94. Yang, L.; Wu, X.H.; Wang, D.; Luo, C.L.; Chen, L.X. Bladder cancer cell-derived exosomes inhibit tumor cell apoptosis and induce cell proliferation in vitro. Mol. Med. Rep. 2013, 8, 1272-1278. [CrossRef] [PubMed]

95. Sento, S.; Sasabe, E.; Yamamoto, T. Application of a Persistent Heparin Treatment Inhibits the Malignant Potential of Oral Squamous Carcinoma Cells Induced by Tumor Cell-Derived Exosomes. PLoS ONE 2016, 11, e0148454. [CrossRef] [PubMed]

96. Smalley, D.M.; Sheman, N.E.; Nelson, K.; Theodorescu, D. Isolation and identification of potential urinary microparticle biomarkers of bladder cancer. J. Proteome Res. 2008, 7, 2088-2096. [CrossRef]

97. Nilsson, J.; Skog, J.; Nordstrand, A.; Baranov, V.; Mincheva-Nilsson, L.; Breakefield, X.O.; Widmark, A. Prostate cancer-derived urine exosomes: A novel approach to biomarkers for prostate cancer. Br. J. Cancer 2009, 100, 1603-1607. [CrossRef]

98. Skog, J.; Wurdinger, T.; van Rijn, S.; Meijer, D.H.; Gainche, L.; Sena-Esteves, M.; Curry, W.T., Jr.; Carter, B.S.; Krichevsky, A.M.; Breakefield, X.O. Glioblastoma microvesicles transport RNA and proteins that promote tumour growth and provide diagnostic biomarkers. Nat. Cell Biol. 2008, 10, 1470-1476. [CrossRef]

99. Khan, S.; Jutzy, J.M.; Valenzuela, M.M.; Turay, D.; Aspe, J.R.; Ashok, A.; Mirshahidi, S.; Mercola, D.; Lilly, M.B.; Wall, N.R. Plasma-derived exosomal survivin, a plausible biomarker for early detection of prostate cancer. PLOS ONE 2012, 7, e46737. [CrossRef]

100. McKiernan, J.; Donovan, M.J.; Margolis, E.; Partin, A.; Carter, B.; Brown, G.; Torkler, P.; Noerholm, M.; Skog, J.; Shore, N.; et al. A Prospective Adaptive Utility Trial to Validate Performance of a Novel Urine Exosome Gene Expression Assay to Predict High-grade Prostate Cancer in Patients with Prostate-specific Antigen 2-10 ng/mL at Initial Biopsy. Eur. Urol. 2018, 74, 731-738. [CrossRef]

101. Li, Q.; Shao, Y.; Zhang, X.; Zheng, T.; Miao, M.; Qin, L.; Wang, B.; Ye, G.; Xiao, B.; Guo, J. Plasma long noncoding RNA protected by exosomes as a potential stable biomarker for gastric cancer. Tumour. Biol. 2015, 36, 2007-2012. [CrossRef] [PubMed]

102. Taylor, D.D.; Gercel-Taylor, C. MicroRNA signatures of tumor-derived exosomes as diagnostic biomarkers of ovarian cancer. Gynecol. Oncol. 2008, 110, 13-21. [CrossRef] [PubMed]

103. Rabinowits, G.; Gercel-Taylor, C.; Day, J.M.; Taylor, D.D.; Kloecker, G.H. Exosomal microRNA: A diagnostic marker for lung cancer. Clin. Lung Cancer 2009, 10, 42-46. [CrossRef] [PubMed]

104. Allenson, K.; Castillo, J.; San Lucas, F.A.; Scelo, G.; Kim, D.U.; Bernard, V.; Davis, G.; Kumar, T.; Katz, M.; Overman, M.J.; et al. High prevalence of mutant KRAS in circulating exosome-derived DNA from early-stage pancreatic cancer patients. Ann. Oncol. 2017, 28, 741-747. [CrossRef]

105. Castellanos-Rizaldos, E.; Grimm, D.G.; Tadigotla, V.; Hurley, J.; Healy, J.; Neal, P.L.; Sher, M.; Venkatesan, R.; Karlovich, C.; Raponi, M.; et al. Exosome-Based Detection of EGFR T790M in Plasma from Non-Small Cell Lung Cancer Patients. Clin. Cancer Res. 2018, 24, 2944-2950. [CrossRef]

106. Yang, S.; Che, S.P.; Kurywchak, P.; Tavormina, J.L.; Gansmo, L.B.; Correa de Sampaio, P.; Tachezy, M.; Bockhorn, M.; Gebauer, F.; Haltom, A.R.; et al. Detection of mutant KRAS and TP53 DNA in circulating exosomes from healthy individuals and patients with pancreatic cancer. Cancer Biol. Ther. 2017, 18, 158-165. [CrossRef]

107. Garcia-Silva, S.; Benito-Martin, A.; Sanchez-Redondo, S.; Hernandez-Barranco, A.; Ximenez-Embun, P.; Nogues, L.; Mazariegos, M.S.; Brinkmann, K.; Amor Lopez, A.; Meyer, L.; et al. Use of extracellular vesicles from lymphatic drainage as surrogate markers of melanoma progression and BRAF(V600E) mutation. J. Exp. Med. 2019, 216, 1061-1070. [CrossRef]

108. Zhao, X.; Wu, D.; Ma, X.; Wang, J.; Hou, W.; Zhang, W. Exosomes as drug carriers for cancer therapy and challenges regarding exosome uptake. Biomed. Pharmacother. 2020, 128, 110237. [CrossRef]

109. Hu, Q.; Su, H.; Li, J.; Lyon, C.; Tang, W.; Wan, M.; Hu, T.Y. Clinical applications of exosome membrane proteins. Precis. Clin. Med. 2020, 3, 54-66. [CrossRef]

110. Johnsen, K.B.; Gudbergsson, J.M.; Skov, M.N.; Pilgaard, L.; Moos, T.; Duroux, M. A comprehensive overview of exosomes as drug delivery vehicles—endogenous nanocarriers for targeted cancer therapy. Biochim. Biophys. Acta. 2014, 1846, 75-87. [CrossRef] 
111. Jaiswal, S.; Jamieson, C.H.; Pang, W.W.; Park, C.Y.; Chao, M.P.; Majeti, R.; Traver, D.; van Rooijen, N.; Weissman, I.L. CD47 is upregulated on circulating hematopoietic stem cells and leukemia cells to avoid phagocytosis. Cell 2009, 138, 271-285. [CrossRef] [PubMed]

112. Haney, M.J.; Klyachko, N.L.; Zhao, Y.; Gupta, R.; Plotnikova, E.G.; He, Z.; Patel, T.; Piroyan, A.; Sokolsky, M.; Kabanov, A.V.; et al. Exosomes as drug delivery vehicles for Parkinson's disease therapy. J. Control. Release 2015, 207, 18-30. [CrossRef] [PubMed]

113. Kim, M.S.; Haney, M.J.; Zhao, Y.; Mahajan, V.; Deygen, I.; Klyachko, N.L.; Inskoe, E.; Piroyan, A.; Sokolsky, M.; Okolie, O.; et al. Development of exosome-encapsulated paclitaxel to overcome MDR in cancer cells. Nanomedicine 2016, 12, 655-664. [CrossRef] [PubMed]

114. Pascucci, L.; Cocce, V.; Bonomi, A.; Ami, D.; Ceccarelli, P.; Ciusani, E.; Vigano, L.; Locatelli, A.; Sisto, F.; Doglia, S.M.; et al. Paclitaxel is incorporated by mesenchymal stromal cells and released in exosomes that inhibit in vitro tumor growth: A new approach for drug delivery. J. Control. Release 2014, 192, 262-270. [CrossRef] [PubMed]

115. Ding, Y.; Cao, F.; Sun, H.; Wang, Y.; Liu, S.; Wu, Y.; Cui, Q.; Mei, W.; Li, F. Exosomes derived from human umbilical cord mesenchymal stromal cells deliver exogenous miR-145-5p to inhibit pancreatic ductal adenocarcinoma progression. Cancer Lett. 2019, 442, 351-361. [CrossRef]

116. Sterzenbach, U.; Putz, U.; Low, L.H.; Silke, J.; Tan, S.S.; Howitt, J. Engineered Exosomes as Vehicles for Biologically Active Proteins. Mol. Ther. 2017, 25, 1269-1278. [CrossRef]

117. Sato, Y.T.; Umezaki, K.; Sawada, S.; Mukai, S.A.; Sasaki, Y.; Harada, N.; Shiku, H.; Akiyoshi, K. Engineering hybrid exosomes by membrane fusion with liposomes. Sci Rep. 2016, 6, 21933. [CrossRef]

118. Lee, J.; Kim, J.; Jeong, M.; Lee, H.; Goh, U.; Kim, H.; Kim, B.; Park, J.H. Liposome-based engineering of cells to package hydrophobic compounds in membrane vesicles for tumor penetration. Nano Lett. 2015, 15, 2938-2944. [CrossRef]

119. Kalimuthu, S.; Gangadaran, P.; Rajendran, R.L.; Zhu, L.; Oh, J.M.; Lee, H.W.; Gopal, A.; Baek, S.H.; Jeong, S.Y.; Lee, S.W.; et al. A New Approach for Loading Anticancer Drugs Into Mesenchymal Stem Cell-Derived Exosome Mimetics for Cancer Therapy. Front. Pharmacol. 2018, 9, 1116. [CrossRef]

120. Saari, H.; Lázaro-Ibáñez, E.; Viitala, T.; Vuorimaa-Laukkanen, E.; Siljander, P.; Yliperttula, M. Microvesicle-and exosome-mediated drug delivery enhances the cytotoxicity of Paclitaxel in autologous prostate cancer cells. J. Control. Release 2015, 220, 727-737. [CrossRef]

121. Jang, S.C.; Kim, O.Y.; Yoon, C.M.; Choi, D.S.; Roh, T.Y.; Park, J.; Nilsson, J.; Lotvall, J.; Kim, Y.K.; Gho, Y.S. Bioinspired exosome-mimetic nanovesicles for targeted delivery of chemotherapeutics to malignant tumors. ACS Nano 2013, 7, 7698-7710. [CrossRef] [PubMed]

122. Tian, Y.; Li, S.; Song, J.; Ji, T.; Zhu, M.; Anderson, G.J.; Wei, J.; Nie, G. A doxorubicin delivery platform using engineered natural membrane vesicle exosomes for targeted tumor therapy. Biomaterials 2014, 35, 2383-2390. [CrossRef] [PubMed]

123. Tang, K.; Zhang, Y.; Zhang, H.; Xu, P.; Liu, J.; Ma, J.; Lv, M.; Li, D.; Katirai, F.; Shen, G.X.; et al. Delivery of chemotherapeutic drugs in tumour cell-derived microparticles. Nat. Commun. 2012, 3, 1282. [CrossRef] [PubMed]

124. Osterman, C.J.; Lynch, J.C.; Leaf, P.; Gonda, A.; Ferguson Bennit, H.R.; Griffiths, D.; Wall, N.R. Curcumin Modulates Pancreatic Adenocarcinoma Cell-Derived Exosomal Function. PLoS ONE 2015, 10, e0132845. [CrossRef] [PubMed]

125. Fu, H.; Yang, H.; Zhang, X.; Wang, B.; Mao, J.; Li, X.; Wang, M.; Zhang, B.; Sun, Z.; Qian, H.; et al. Exosomal TRIM3 is a novel marker and therapy target for gastric cancer. J. Exp. Clin. Cancer Res. 2018, 37, 162. [CrossRef] [PubMed]

126. Mizrak, A.; Bolukbasi, M.F.; Ozdener, G.B.; Brenner, G.J.; Madlener, S.; Erkan, E.P.; Strobel, T.; Breakefield, X.O.; Saydam, O. Genetically engineered microvesicles carrying suicide mRNA/protein inhibit schwannoma tumor growth. Mol. Ther. 2013, 21, 101-108. [CrossRef]

127. Rivoltini, L.; Chiodoni, C.; Squarcina, P.; Tortoreto, M.; Villa, A.; Vergani, B.; Burdek, M.; Botti, L.; Arioli, I.; Cova, A.; et al. TNF-Related Apoptosis-Inducing Ligand (TRAIL)-Armed Exosomes Deliver Proapoptotic Signals to Tumor Site. Clin. Cancer Res. 2016, 22, 3499-3512. [CrossRef] 
128. Andre, F.; Chaput, N.; Schartz, N.E.; Flament, C.; Aubert, N.; Bernard, J.; Lemonnier, F.; Raposo, G.; Escudier, B.; Hsu, D.H.; et al. Exosomes as potent cell-free peptide-based vaccine. I. Dendritic cell-derived exosomes transfer functional MHC class I/peptide complexes to dendritic cells. J. Immunol. 2004, 172, 2126-2136. [CrossRef]

129. Xie, Y.; Bai, O.; Zhang, H.; Yuan, J.; Zong, S.; Chibbar, R.; Slattery, K.; Qureshi, M.; Wei, Y.; Deng, Y.; et al. Membrane-bound HSP70-engineered myeloma cell-derived exosomes stimulate more efficient CD8(+) CTLand NK-mediated antitumour immunity than exosomes released from heat-shocked tumour cells expressing cytoplasmic HSP70. J. Cell Mol. Med. 2010, 14, 2655-2666. [CrossRef]

130. Kooijmans, S.A.; Aleza, C.G.; Roffler, S.R.; van Solinge, W.W.; Vader, P.; Schiffelers, R.M. Display of GPI-anchored anti-EGFR nanobodies on extracellular vesicles promotes tumour cell targeting. J. Extracell. Vesicles 2016, 5, 31053. [CrossRef]

131. Koh, E.; Lee, E.J.; Nam, G.H.; Hong, Y.; Cho, E.; Yang, Y.; Kim, I.S. Exosome-SIRPalpha, a CD47 blockade increases cancer cell phagocytosis. Biomaterials 2017, 121, 121-129. [CrossRef] [PubMed]

132. Ohno, S.; Takanashi, M.; Sudo, K.; Ueda, S.; Ishikawa, A.; Matsuyama, N.; Fujita, K.; Mizutani, T.; Ohgi, T.; Ochiya, T.; et al. Systemically injected exosomes targeted to EGFR deliver antitumor microRNA to breast cancer cells. Mol. Ther. 2013, 21, 185-191. [CrossRef]

133. Katakowski, M.; Buller, B.; Zheng, X.; Lu, Y.; Rogers, T.; Osobamiro, O.; Shu, W.; Jiang, F.; Chopp, M. Exosomes from marrow stromal cells expressing miR-146b inhibit glioma growth. Cancer Lett. 2013, 335, 201-204. [CrossRef] [PubMed]

134. Lou, G.; Song, X.; Yang, F.; Wu, S.; Wang, J.; Chen, Z.; Liu, Y. Exosomes derived from miR-122-modified adipose tissue-derived MSCs increase chemosensitivity of hepatocellular carcinoma. J. Hematol. Oncol. 2015, 8, 122. [CrossRef] [PubMed]

135. Wang, F.; Li, L.; Piontek, K.; Sakaguchi, M.; Selaru, F.M. Exosome miR-335 as a novel therapeutic strategy in hepatocellular carcinoma. Hepatology 2018, 67, 940-954. [CrossRef] [PubMed]

136. O'Brien, K.P.; Khan, S.; Gilligan, K.E.; Zafar, H.; Lalor, P.; Glynn, C.; O'Flatharta, C.; Ingoldsby, H.; Dockery, P.; De Bhulbh, A.; et al. Employing mesenchymal stem cells to support tumor-targeted delivery of extracellular vesicle (EV)-encapsulated microRNA-379. Oncogene 2018, 37, 2137-2149. [CrossRef] [PubMed]

137. Zeng, Z.; Li, Y.; Pan, Y.; Lan, X.; Song, F.; Sun, J.; Zhou, K.; Liu, X.; Ren, X.; Wang, F.; et al. Cancer-derived exosomal miR-25-3p promotes pre-metastatic niche formation by inducing vascular permeability and angiogenesis. Nat. Commun. 2018, 9, 5395. [CrossRef]

138. Greco, K.A.; Franzen, C.A.; Foreman, K.E.; Flanigan, R.C.; Kuo, P.C.; Gupta, G.N. PLK-1 Silencing in Bladder Cancer by siRNA Delivered With Exosomes. Urology 2016, 91, e1-e7. [CrossRef]

139. Li, H.; Yang, C.; Shi, Y.; Zhao, L. Exosomes derived from siRNA against GRP78 modified bone-marrow-derived mesenchymal stem cells suppress Sorafenib resistance in hepatocellular carcinoma. J. Nanobiotechnol. 2018, 16, 103. [CrossRef]

140. Shokrollahi, E.; Nourazarian, A.; Rahbarghazi, R.; Salimi, L.; Karbasforush, S.; Khaksar, M.; Salarinasab, S.; Abhari, A.; Heidarzadeh, M. Treatment of human neuroblastoma cell line SH-SY5Y with HSP27 siRNA tagged-exosomes decreased differentiation rate into mature neurons. J. Cell Physiol. 2019, 234, 21005-21013. [CrossRef]

141. Usman, W.M.; Pham, T.C.; Kwok, Y.Y.; Vu, L.T.; Ma, V.; Peng, B.; Chan, Y.S.; Wei, L.; Chin, S.M.; Azad, A.; et al. Efficient RNA drug delivery using red blood cell extracellular vesicles. Nat. Commun. 2018, 9, 2359. [CrossRef] [PubMed]

142. Yang, Z.; Shi, J.; Xie, J.; Wang, Y.; Sun, J.; Liu, T.; Zhao, Y.; Zhao, X.; Wang, X.; Ma, Y.; et al. Large-scale generation of functional mRNA-encapsulating exosomes via cellular nanoporation. Nat. Biomed. Eng. 2020, 4, 69-83. [CrossRef] [PubMed]

143. Mao, L.; Li, X.; Gong, S.; Yuan, H.; Jiang, Y.; Huang, W.; Sun, X.; Dang, X. Serum exosomes contain ECRG4 mRNA that suppresses tumor growth via inhibition of genes involved in inflammation, cell proliferation, and angiogenesis. Cancer Gene Ther. 2018, 25, 248-259. [CrossRef] [PubMed]

144. Ell, B.; Mercatali, L.; Ibrahim, T.; Campbell, N.; Schwarzenbach, H.; Pantel, K.; Amadori, D.; Kang, Y. Tumor-induced osteoclast miRNA changes as regulators and biomarkers of osteolytic bone metastasis. Cancer Cell 2013, 24, 542-556. [CrossRef] [PubMed] 
145. Yang, L.; Zhang, L.; Lu, L.; Wang, Y. lncRNA UCA1 Increases Proliferation and Multidrug Resistance of Retinoblastoma Cells Through Downregulating miR-513a-5p. DNA Cell Biol. 2020, 39, 69-77. [CrossRef] [PubMed]

146. Syn, N.L.; Wang, L.; Chow, E.K.; Lim, C.T.; Goh, B.C. Exosomes in Cancer Nanomedicine and Immunotherapy: Prospects and Challenges. Trends Biotechnol. 2017, 35, 665-676. [CrossRef] [PubMed]

147. Munich, S.; Sobo-Vujanovic, A.; Buchser, W.J.; Beer-Stolz, D.; Vujanovic, N.L. Dendritic cell exosomes directly kill tumor cells and activate natural killer cells via TNF superfamily ligands. Oncoimmunology 2012, 1, 1074-1083. [CrossRef]

148. Viaud, S.; Terme, M.; Flament, C.; Taieb, J.; Andre, F.; Novault, S.; Escudier, B.; Robert, C.; Caillat-Zucman, S.; Tursz, T.; et al. Dendritic cell-derived exosomes promote natural killer cell activation and proliferation: A role for NKG2D ligands and IL-15Ralpha. PLoS ONE 2009, 4, e4942. [CrossRef]

149. Viaud, S.; Ploix, S.; Lapierre, V.; Thery, C.; Commere, P.H.; Tramalloni, D.; Gorrichon, K.; Virault-Rocroy, P.; Tursz, T.; Lantz, O.; et al. Updated technology to produce highly immunogenic dendritic cell-derived exosomes of clinical grade: A critical role of interferon-gamma. J. Immunother. 2011, 34, 65-75. [CrossRef]

150. Damo, M.; Wilson, D.S.; Simeoni, E.; Hubbell, J.A. TLR-3 stimulation improves anti-tumor immunity elicited by dendritic cell exosome-based vaccines in a murine model of melanoma. Sci. Rep. 2015, 5, 17622. [CrossRef]

151. Besse, B.; Charrier, M.; Lapierre, V.; Dansin, E.; Lantz, O.; Planchard, D.; Le Chevalier, T.; Livartoski, A.; Barlesi, F.; Laplanche, A.; et al. Dendritic cell-derived exosomes as maintenance immunotherapy after first line chemotherapy in NSCLC. Oncoimmunology 2016, 5, e1071008. [CrossRef] [PubMed]

152. Naslund, T.I.; Gehrmann, U.; Qazi, K.R.; Karlsson, M.C.; Gabrielsson, S. Dendritic cell-derived exosomes need to activate both $\mathrm{T}$ and $\mathrm{B}$ cells to induce antitumor immunity. J. Immunol. 2013, 190, 2712-2719. [CrossRef] [PubMed]

153. Hiltbrunner, S.; Larssen, P.; Eldh, M.; Martinez-Bravo, M.J.; Wagner, A.K.; Karlsson, M.C.; Gabrielsson, S. Exosomal cancer immunotherapy is independent of MHC molecules on exosomes. Oncotarget 2016, 7, 38707-38717. [CrossRef] [PubMed]

154. Pitt, J.M.; Andre, F.; Amigorena, S.; Soria, J.C.; Eggermont, A.; Kroemer, G.; Zitvogel, L. Dendritic cell-derived exosomes for cancer therapy. J. Clin. Investig. 2016, 126, 1224-1232. [CrossRef] [PubMed]

155. Srinivasan, S.; Vannberg, F.O.; Dixon, J.B. Lymphatic transport of exosomes as a rapid route of information dissemination to the lymph node. Sci. Rep. 2016, 6, 24436. [CrossRef] [PubMed]

156. Fu, W.; Lei, C.; Liu, S.; Cui, Y.; Wang, C.; Qian, K.; Li, T.; Shen, Y.; Fan, X.; Lin, F.; et al. CAR exosomes derived from effector CAR-T cells have potent antitumour effects and low toxicity. Nat. Commun. 2019, 10, 4355. [CrossRef]

157. Vafaizadeh, V.; Barekati, Z. Immuno-Oncology Biomarkers for Personalized Immunotherapy in Breast Cancer. Front. Cell Dev. Biol. 2020, 8, 162. [CrossRef]

158. Dai, L.J.; Moniri, M.R.; Zeng, Z.R.; Zhou, J.X.; Rayat, J.; Warnock, G.L. Potential implications of mesenchymal stem cells in cancer therapy. Cancer Lett. 2011, 305, 8-20. [CrossRef]

159. Kim, H.S.; Choi, D.Y.; Yun, S.J.; Choi, S.M.; Kang, J.W.; Jung, J.W.; Hwang, D.; Kim, K.P.; Kim, D.W. Proteomic analysis of microvesicles derived from human mesenchymal stem cells. J. Proteome Res. 2012, 11, 839-849. [CrossRef]

(C) 2020 by the authors. Licensee MDPI, Basel, Switzerland. This article is an open access article distributed under the terms and conditions of the Creative Commons Attribution (CC BY) license (http://creativecommons.org/licenses/by/4.0/). 